Provided for non-commercial research and education use. Not for reproduction, distribution or commercial use.

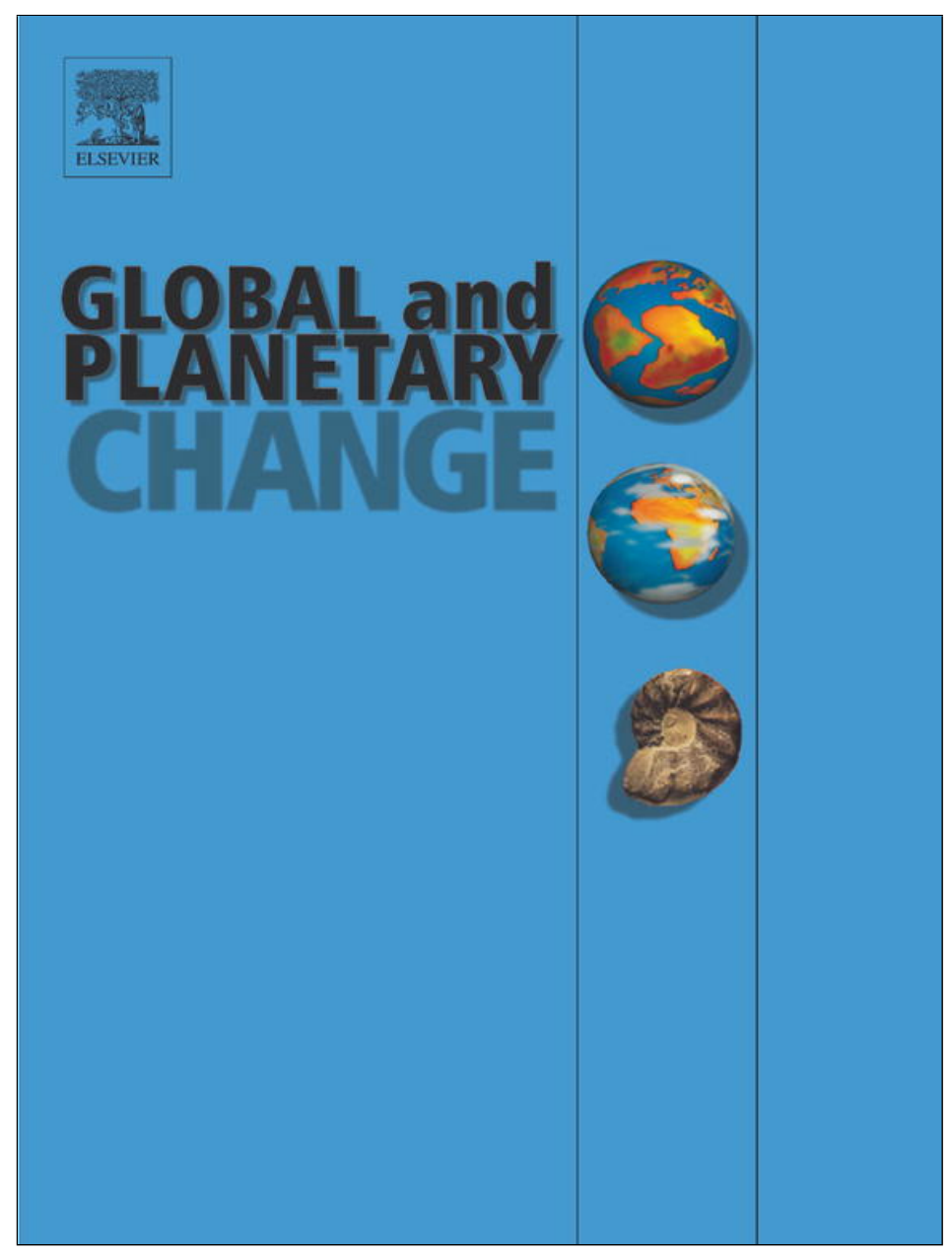

This article appeared in a journal published by Elsevier. The attached copy is furnished to the author for internal non-commercial research and education use, including for instruction at the authors institution and sharing with colleagues.

Other uses, including reproduction and distribution, or selling or licensing copies, or posting to personal, institutional or third party websites are prohibited.

In most cases authors are permitted to post their version of the article (e.g. in Word or Tex form) to their personal website or institutional repository. Authors requiring further information regarding Elsevier's archiving and manuscript policies are encouraged to visit:

http://www.elsevier.com/authorsrights 


\title{
A 70,000 year multiproxy record of climatic and environmental change from Rano Aroi peatland (Easter Island)
}

\author{
Olga Margalef a,*, Núria Cañellas-Boltà b,c , Sergi Pla-Rabes ${ }^{\text {d,e }}$, Santiago Giralt ${ }^{\mathrm{a}}$, Juan Jose Pueyo ${ }^{\mathrm{c}}$, \\ Hans Joosten ${ }^{\mathrm{f}}$, Valentí Rull ${ }^{\mathrm{b}}$, Teresa Buchaca ${ }^{\mathrm{e}}$, Armand Hernández ${ }^{\mathrm{g}}$, Blas L. Valero-Garcés ${ }^{\mathrm{h}}$, \\ Ana Moreno ${ }^{\mathrm{h}}$, Alberto Sáez ${ }^{\mathrm{c}}$
}

a Institute of Earth Sciences Jaume Almera CSIC, Lluís Solé i Sabarís s/n, E-08028 Barcelona, Spain

${ }^{b}$ Laboratory of Palynology and Paleocology, Botanic Institute of Barcelona (IBB-CSIC-ICUB), Spain

c Faculty of Geology, University of Barcelona, Martí $i$ Franquès s/n, E-08028 Barcelona, Spain

d Ecological Research Center and Forestry Applications (CREAF), Campus de Bellaterra (UAB) Cerdanyola del Vallès, Barcelona, Spain

e Advanced Studies Center of Blanes, C/D'accés a la Cala St. Francesc, 14, Blanes, Girona E-17300, Spain

${ }^{\mathrm{f}}$ Institute of Botany and Landscape Ecology, Grimmer Strasse 88, D-17487 Greifswald, Germany

g IDL, Faculty of Sciences, University of Lisbon, Lisbon, Portugal

h Pyrenean Institute of Ecology CSIC, Avda. de Montañana, 1005, 50059 Zaragoza, Spain

\section{A R T I C L E I N F O}

\section{Article history:}

Received 27 September 2012

Accepted 29 May 2013

Available online 14 June 2013

\section{Keywords:}

South Pacific paleoclimate

Peat geochemistry

Stable isotopes

X-ray fluorescence core scanner

Marine Isotope Stage 3

Last Glacial Maximum

Holocene

\begin{abstract}
A B S T R A C T
The Rano Aroi mire on Easter Island (also known as Rapa Nui; $27^{\circ} 09^{\prime} \mathrm{S}, 109^{\circ} 27^{\prime} \mathrm{W}, 430 \mathrm{~m}$ above sea level) provides a unique non-marine record in the central South Pacific Ocean for reconstructing Late Pleistocene environmental changes. The results of a multiproxy study on two cores from the center and margin of the Rano Aroi mire, including peat stratigraphy, facies analysis, elemental and isotope geochemistry on bulk organic matter, X-ray fluorescence (XRF) core scanning and macrofossil analysis, were used to infer past water levels and vegetation changes. The chronology was based on 18 14C AMS dates for the upper $8.7 \mathrm{~m}$. The extrapolated age for the base of the sequence is $70 \mathrm{kyr}$, which implies that this record is the oldest paleolimnological record on Easter Island. The recovered Rano Aroi sequence consists of a radicel peat formed primarily from the remains of sedges, grasses and Polygonaceae that have accumulated since Marine Isotopic Stage (MIS) 4 (70 kyr BP) to the present. From 60 to $40 \mathrm{kyr}$ BP (MIS 3), high precipitation/runoff events were recorded as organic mud facies with lighter $\delta^{13} \mathrm{C}$, low $\mathrm{C} / \mathrm{N}$ values and high Ti content, indicating higher detritic input to the mire. A gradual shift in $\delta^{13} \mathrm{C}$ bulk organic matter from $-14 \%$ to $-26 \%$, recorded between 50 and 45 cal kyr BP, suggests a progressive change in local peat-forming vegetation from C4 to C3 plant types. Post-depositional Ca and Fe enrichment during sub-aerial peat exposure and very low sedimentation rates indicate lower water tables during Late MIS 3 (3931 cal kyr BP). During MIS 2 (27.8-19 cal kyr BP), peat production rates were very low, most likely due to cold temperatures, as reconstructed from other Easter Island records during the Last Glacial Maximum (LGM). Geochemical and macrofossil evidence shows that peat accumulation reactivates at approximately $17.5 \mathrm{cal} \mathrm{kyr}$ $\mathrm{BP}$, reaching the highest accumulation rates at $14 \mathrm{cal}$ kyr BP. Peat accretion decreased from 5.0 to $2.5 \mathrm{cal} \mathrm{kyr}$ $\mathrm{BP}$, coinciding with a regional Holocene aridity phase. The main hydrological and environmental changes in Rano Aroi reflect variations in the South Pacific Convergence Zone (SPCZ), Southern Westerlies (SW) storm track, and South Pacific Anticyclone (SPA) locations.
\end{abstract}

(C) 2013 Elsevier B.V. All rights reserved.

\section{Introduction}

Peatlands are globally important paleoenvironmental archives because they contain abundant carbon for dating and hold a wide range of hydroclimatically sensitive paleoenvironmental proxies (de Jong et al., 2010; Jackson and Charman, 2010). Peatland research has been mainly focused on the ecology of boreal and temperate mires (Gorham, 1991; Grootjans et al., 2006). However, the paleoenvironmental evolution of

\footnotetext{
* Corresponding author. Tel.: + 34934095410.

E-mail address: omargalef@ictja.csic.es (0. Margalef).
}

tropical and subtropical peatlands has received increased attention (Page et al., 2006; Muller et al., 2008; Dommain et al., 2011). Recent geochemical studies have addressed the origin and distribution of major and trace elements to reconstruct environmental changes (Weiss et al., 2002; Bindler, 2006; Muller et al., 2006; Kylander et al., 2007), and macrofossil remains such as seeds and invertebrates have been useful proxies to reflect the local flora and fauna in mire deposits (Barber et al., 2003; Birks and Birks, 2006).

The Late Pleistocene and Holocene climates of the Pacific and Circumpacific regions have been reconstructed from marine and terrestrial records (Lamy et al., 1998; Stuut and Lamy, 2004; Valero-Garcés et 
al., 2005; Heusser and Heusser, 2006; Muller, 2006; Wang et al., 2007; Pena et al., 2008). Despite the relevance of the Southern Pacific region for global climate dynamics, paleo-oceanographic studies in central Pacific are scarce (Pena et al., 2008) because sedimentation rates on abyssal zones are too low for high-resolution reconstructions. For this reason, continental records from Eastern Island represent key archives to understand Late Pleistocene Circumpacific climate evolution and millennial time-scale changes in the El Niño-Southern Oscillation (ENSO).

Paleo-environmental reconstructions from Easter Island have traditionally been based on pollen studies (Flenley and King, 1984; Flenley et al., 1991; Dumont et al., 1998; Butler et al., 2004; Gossen, 2007; Azizi and Flenley, 2008; Mann et al., 2008) and macrofossil remains (Dumont et al., 1998; Orliac and Orliac, 1998; Orliac, 2000; Peteet et al., 2003; Horrocks and Wozniak, 2008; Mann et al., 2008; Cañellas-Boltá et al., 2012). Many studies focused on the timing of human arrival, societal evolution and deforestation because those matters remain still controversial. Several studies have also described local responses to regional Last Glacial and Holocene paleoclimatic evolution (Flenley et al., 1991; Azizi and Flenley, 2008). Recently, multiproxy studies of the sediments of Raraku Lake, which combined sedimentological, mineralogical, geochemical and macrofossil data, allowed a detailed reconstruction of the large hydrological changes that have taken place on Easter Island since ca. 34 cal kyr BP (Sáez et al., 2009; Cañellas-Boltá et al., 2012). Concordant geological and biological proxies have characterized the glacial period as cold and relatively humid, ending in the two-step Termination 1 (17.3-12.5 cal kyr BP). From 11.2 cal kyr BP, the Raraku Lake record shows a decreasing water availability trend, whereas intense drought periods during the Middle and Late Holocene were responsible for a long sedimentary gap from 4.2 cal kyr BP to 800 yr BP (Sáez et al., 2009; Cañellas-Boltá et al., 2012). Sedimentation resumed approximately $700 \mathrm{cal}$ yr BP with the onset of a humid period.

Fewer studies have focused on the Late Pleistocene evolution of Rano Aroi, a small mire situated on Easter Island (Flenley et al., 1991; Peteet et al., 2003). The aim of this paper is to provide new insights into Rano Aroi environmental history as revealed from highresolution multiproxy analyses from two peat cores. In this study we present new geochemical profiles (TC, TN, $\delta^{13} \mathrm{C}, \mathrm{Ti}, \mathrm{Fe}, \mathrm{Ca}$ content), peat facies description and macrofossil analyses from the longest record hitherto obtained from Easter Island. The reconstructed water level and vegetational changes during the last $70 \mathrm{kyr}$ have been integrated with and tested against the results of previous studies from Raraku and Kao lacustrine records and other marine and terrestrial sequences from $\mathrm{Pa}-$ cific and Circumpacific areas (Lamy et al., 1998; Stuut and Lamy, 2004; Valero-Garcés et al., 2005; Heusser and Heusser, 2006; Muller, 2006; Wang et al., 2007; Pena et al., 2008).

\section{Regional setting}

Easter Island $\left(27^{\circ} 07^{\prime} \mathrm{S}, 109^{\circ} 22^{\prime} \mathrm{W}\right)$, known as Rapa Nui in the local indigenous language, is a small Miocene volcanic island in the southern Pacific Ocean, located $3510 \mathrm{~km}$ from the South American continent. The topography is characterized by more than 70 volcano craters and the rolling surfaces of lava flows (Baker et al., 1974; González-Ferran et al., 2004).

The climate is subtropical, with average monthly temperatures between $18{ }^{\circ} \mathrm{C}$ and $24{ }^{\circ} \mathrm{C}$ (Junk and Claussen, 2011) and highly variable annual rainfall (mean of $1130 \mathrm{~mm}$ ). Three interacting meteorological phenomena control precipitation in the eastern Pacific: the South Pacific Anticyclone (SPA), cyclonic storms carried in by the Southern Westerlies (SW) and the South Pacific Convergence Zone (SPCZ) (Fig. 1). The weakening of the SPA during the winter and the northward migration of the SPCZ and SW lead to the highest precipitation from April to July. In the winter, rainfall occurs due to depression fronts, while summer rain is mainly driven by the land-sea breeze and convection induced by the warmer Sea Surface Temperatures (SST) and Easter Island orography (Mucciarone and Dunbar, 2003; Junk and Claussen, 2011). No correlation has been found between ENSO and rainfall on Easter Island (MacIntyre, 2001a, 2001b; Genz and Hunt, 2003), although ENSO variability and dynamics are responsible for changes in the SST and the predominant wind direction in the region (Mucciarone and Dunbar, 2003; Anderson et al., 2006).

There are three permanent inland wetlands in the island: the craters of Rano Raraku and Rano Kau occupied by lakes, and Rano Aroi. Except for a few coastal creeks, a surface drainage network does not exist in Easter Island, because precipitation infiltrates immediately in the very pervious lava flows (Herrera and Custodio, 2008). The flora and fauna of the island exhibit low diversity and have been almost completely altered by humans (Zizka, 1991; Rull et al., 2010a). Today, the island is largely covered by meadows that are dominated

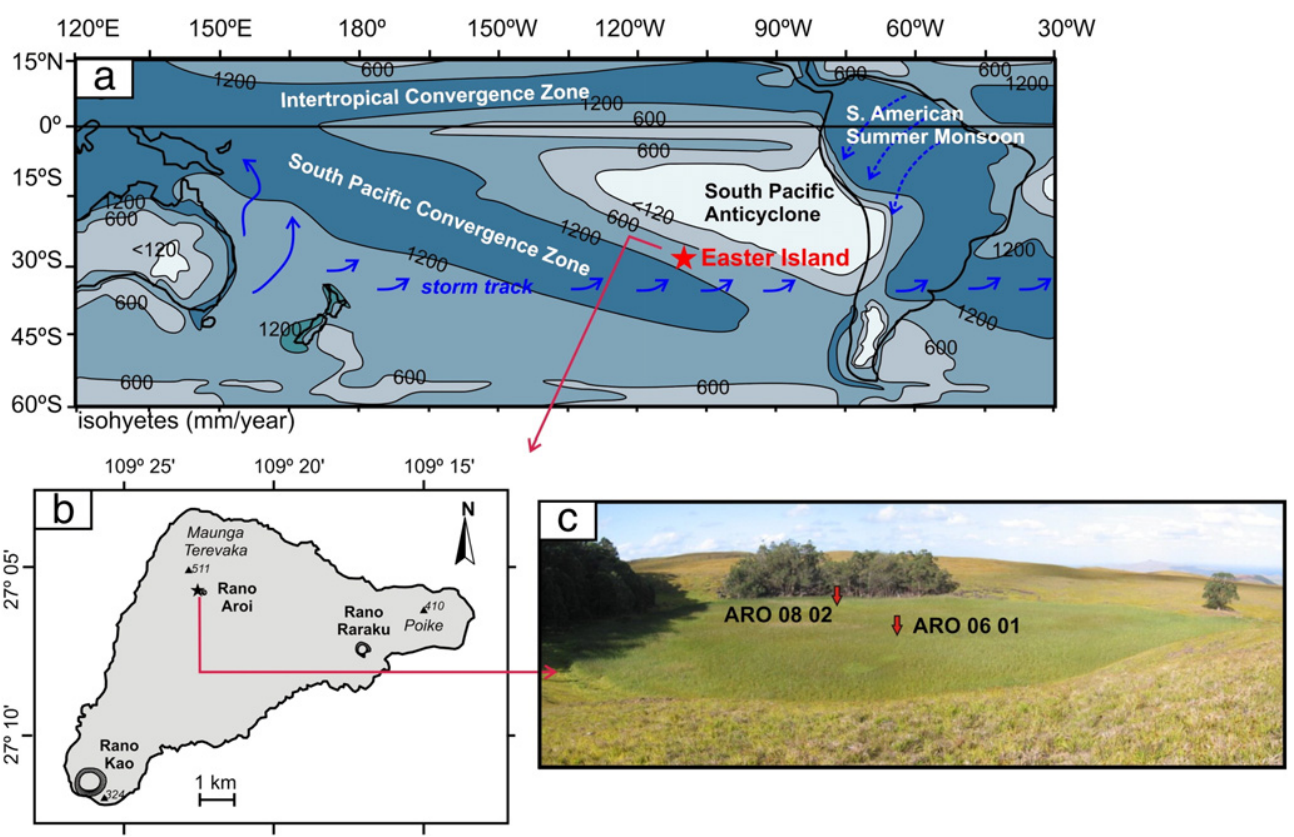

Fig. 1. a) Location of Easter Island on a southern Pacific Ocean rainfall rate map (mm/year) and main atmospheric systems, modified from Sáez et al. (2009). b) Map showing the position of Rano Aroi on the island. c) Photo of the Rano Aroi mire, indicating the location of the cores studied in this work (ARO 0601 , center of the mire and ARO 0802 , edge of the mire). 


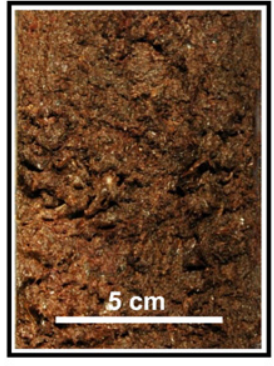

Facies A Reddish peat

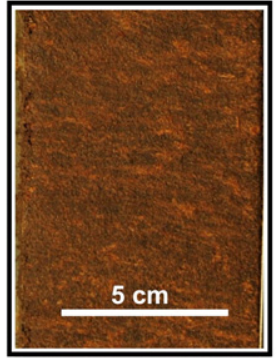

Facies B Granulated muddy peat

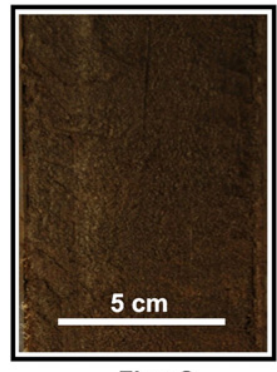

Fine C

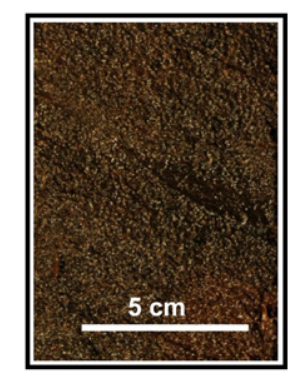

Facies D

Sapric peat

Fig. 2. Peat facies from Rano Aroi: Facies A (reddish peat), Facies B (granulated muddy peat), Facies C (organic mud), and Facies D (sapric peat).

by grasses (90\%), few tree plantations (mainly Eucalyptus), shrubland, and secondary pioneer vegetation (Etienne et al., 1982; Rull et al., 2010a).

The Rano Aroi mire $\left(27^{\circ} \mathrm{S}, 108^{\circ} \mathrm{W}, 430 \mathrm{~m}\right.$ elevation $)$ is located in an ancient Pleistocene volcano crater near the highest summit of the island, Mauna Terevaka (511 m) (Fig. 1). The gentle crater slopes form a small catchment area (15.82 ha) of very porphyritic olivinic tholeite, basalt and hawaiite lava flows (González-Ferran et al., 2004) that are covered by grassland and planted eucalyptus. The mire $\left(0.13 \mathrm{~km}^{2}\right)$ almost fully fills the basin and is covered by vegetation that is dominated by Scirpus californicus, Polygonum acuminatum, Asplenium polyodon var. squamulosum, Vittaria elongata and Cyclosorus interruptus (Zizka, 1991).

The natural outflow follows a small ravine and infiltrates before reaching the coast. The construction of an artificial outlet in the 1960s partially drained the basin, and the water levels have been controlled since that time. The chemical composition of the flowing Rano Aroi outlet (slightly acidic, $\mathrm{pH}=5.5-6.5$ ) is similar to that of the groundwater, indicating that it represents the discharge of the main aquifer or a perched spring of a highly saturated zone (Herrera and Custodio, 2008). Water isotopic data $\left(\delta^{18} \mathrm{O}, \delta^{2} \mathrm{H}\right)$ show that - unlike the closed waterbodies of Rano Kau and Rano Raraku that are controlled by rainfall and evaporation - the residence time of Rano Aroi water is short and the water is renewed through discharge from an aquifer very sensitive to seasonal variations in precipitation (Herrera and Custodio, 2008). Therefore, Rano Aroi can be characterized as a geogenous fen, a peatland or mire fed by groundwater or water that has been in close contact with the mineral soil or bedrock (Joosten and Clarke, 2002; Grootjans et al., 2006).

\section{Material and methods}

Two sediment cores (ARO 06 01, ARO 06 02) reaching 13.9 and $16.3 \mathrm{~m}$ depth, respectively, were recovered with a UWITEC corer from the central part of Rano Aroi during a drilling expedition in March 2006. The uppermost two meters of the sequence were rejected to avoid potential anthropic remobilization, as described in previous studies. The cores were sealed, transported to the laboratory and stored at $+4{ }^{\circ} \mathrm{C}$ until sampling. In October 2008, three cores up to $4 \mathrm{~m}$ in depth were retrieved with a Russian corer from the eastern margins of the mire (ARO 0801 , ARO 0802 , ARO 08 03), an area that was potentially not affected by recent human activities (Flenley and King, 1984; Flenley et al., 1991). None of the cores retrieved in either campaign reached the bedrock. This study focused on the $13.9-\mathrm{m}$ deep core from the center of the mire (ARO 06 01) and a 4-m deep core from the edge of the mire (ARO 08 02). Both cores were lithologically described and sampled for smear slides every $5 \mathrm{~cm}$. Age models for both cores were constructed from 27 radiocarbon AMS dates of pollen concentrates that were prepared by acid digestion (Rull et al., 2010b) and measured at the Poznan Radiocarbon Laboratory (Poland).
The obtained ages were calibrated using CALIB 6.02 software and the INTCAL 09 curve (Reimer et al., 2004) for samples younger than 20 kyr BP and CalPal online calibrated to a Hulu curve (Weninger et al., 2008) for older samples (Danzeglocke et al., 2008). No reservoir effect correction was applied to the radiocarbon dates since the dated pollen predominantly derived from sedges and other emergent and surrounding vegetation using atmospheric $\mathrm{CO}_{2}$, and the pollen enriched concentrates did not contain significant amounts of amorphous organic matter that could have been of aquatic origin. Beyond the radiocarbon limit, ages were extrapolated using average accumulation rates (see Section 5.1 for details).

Cores were sampled every $5 \mathrm{~cm}$, dried at $60{ }^{\circ} \mathrm{C}$ for $48 \mathrm{~h}$, frozen with liquid nitrogen, ground in a ring mill and analyzed for total carbon (TC), total nitrogen (TN) (RSD, $5 \%$ of the measurements) and $\delta^{13} \mathrm{C}$ ( $0.2 \%$ of analytical precision) using a Finnigan delta Plus EA-CF-IRMS spectrometer at the Serveis Cientifico-Tècnics of the Universitat de Barcelona (SCT-UB). The carbonate content was below the detection

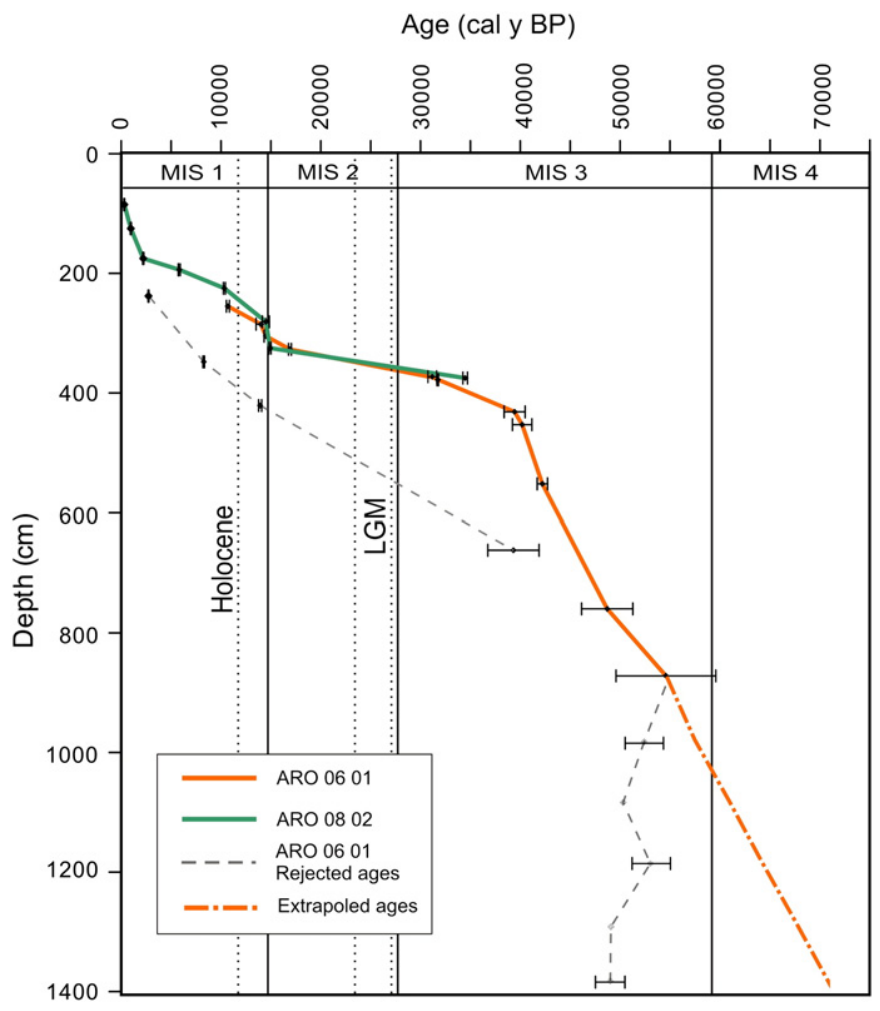

Fig. 3. Rano Aroi sequence age model. Samples from ARO 0601 (central core section) and ARO 0802 (marginal core section). Error bars for each point are shown. Ages in dashed lines were rejected (see text for details). Dotted line indicates extrapolated ages (see text for details). The recovered sequence of Rano Aroi spans the last $70 \mathrm{kyr}$ BP. 
II I I I

III. I.

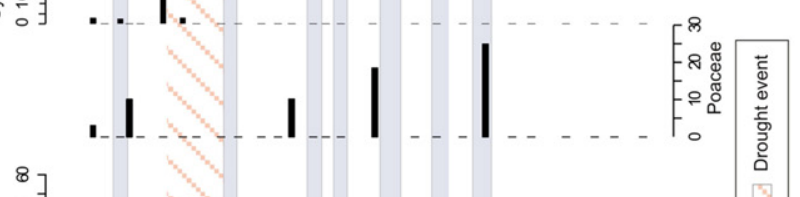

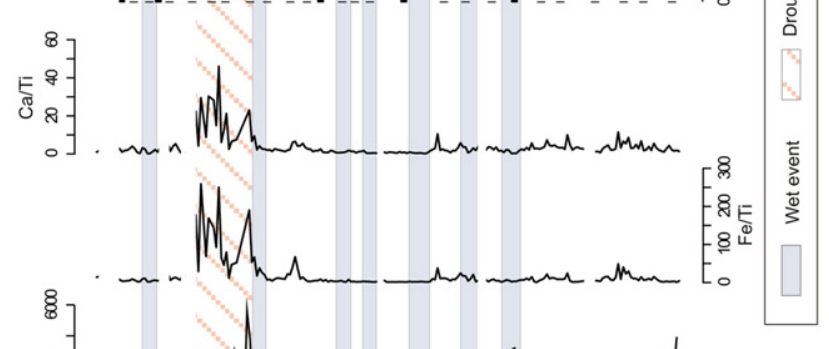

0.

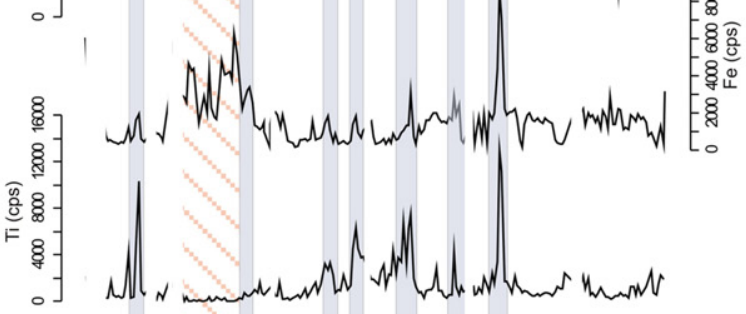

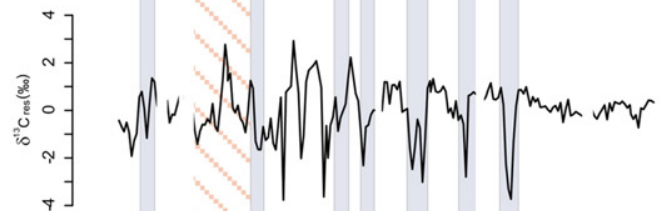

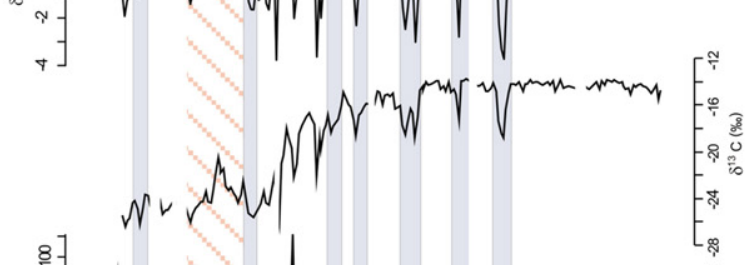

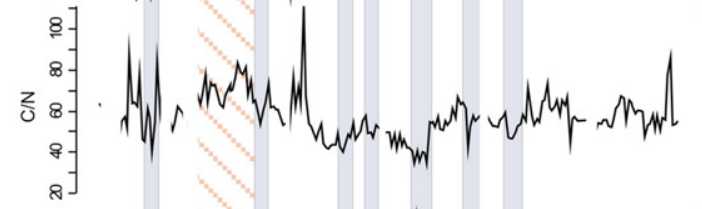

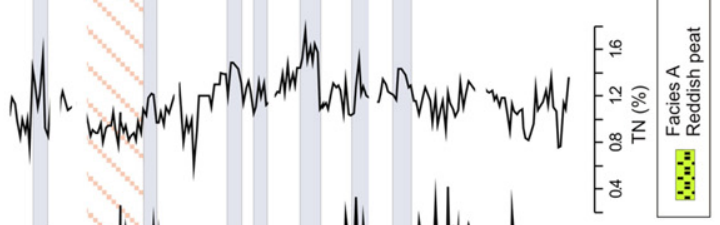

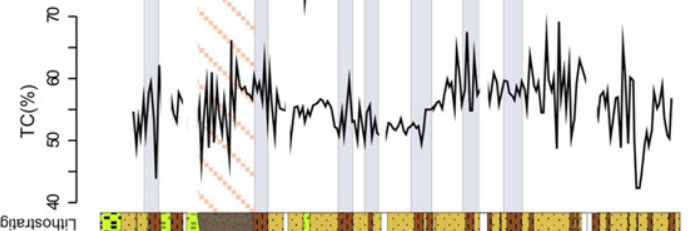

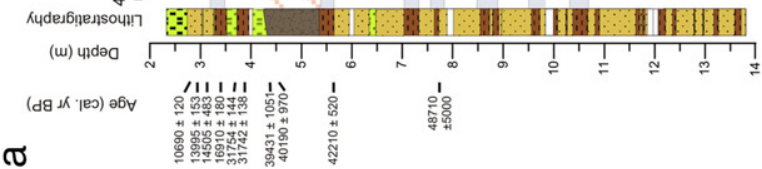

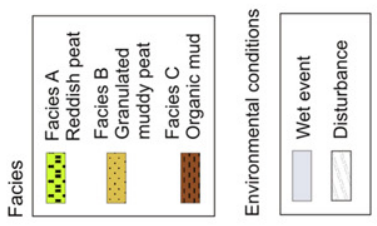

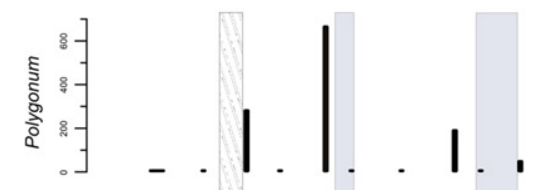

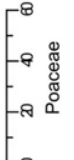

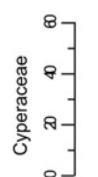

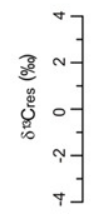

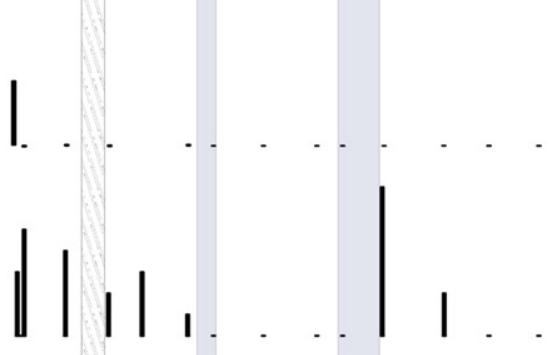

Mhand Mh

MNhm Mrm

s

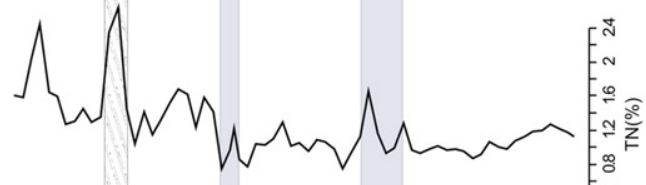
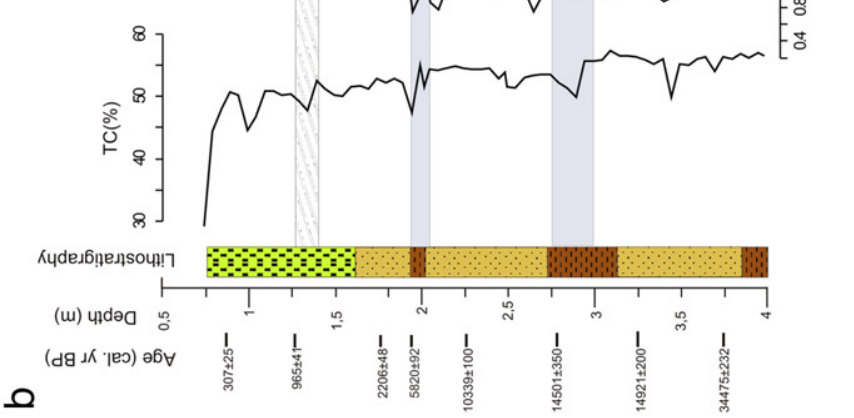
limit; consequently, total carbon (TC) was considered to be equal to Total Organic Carbon (TOC). $\delta^{13} \mathrm{C}$ variability $\left(\delta^{13} \mathrm{C}_{\mathrm{res}}\right)$ was analyzed by subtracting a 19-sample mean running average from the raw $\delta^{13} \mathrm{C}$ data to highlight high-frequency events compared to long-term tendencies.

The iron ( $\mathrm{Fe})$, titanium (Ti) and calcium (Ca) relative counts and $\mathrm{X}$-ray radiographs were obtained every $2 \mathrm{~mm}$ for ARO 0601 with a new-generation XRF ITRAX core scanner (Mo and $\mathrm{Cr}$ tube at $30 \mathrm{kV}$ and $20 \mathrm{~mA}$ measuring $60 \mathrm{~s}$ ) of the Large Lakes Observatory (University of Minnesota, Duluth, MN).

Morphological and elemental Energy-dispersive X-ray spectroscopy (EDS) analyses of sand grains with high mineral contents $(4.8 \mathrm{~m}$, $8.3 \mathrm{~m}$ and $10.55 \mathrm{~m}$ core depth) were performed with an environmental scanning electron microscope (ESEM, FEI QUANTA) operating in a low vacuum ( 0.5 Torr) and a scanning electron microscope (SEM, FEI) operating in a high vacuum $\left(<10^{-4}\right.$ Torr).

Samples $\left(30-45 \mathrm{~cm}^{3}\right)$ for plant macrofossil analysis were extracted from ARO 0601 (30 samples, 1 sample every $45 \mathrm{~cm}$ ) and ARO 0802 (16 samples, 1 sample every $20 \mathrm{~cm}$ ), measured by water displacement, and sieved over $125-\mu \mathrm{m}$ and $500-\mu \mathrm{m}$ sieves with a gentle stream of tap water (Birks, 2001). The residues were examined systematically under a stereomicroscope at $12 \times$ magnification. The identification of macrofossils (seeds, coleoptera and oribatid mites) was carried out by comparisons with reference materials (Birks, 2001). The remains were stored in the general reference collection of biological micro and macro remains at the Botanical Institute of Barcelona with the nomenclature code IBB- for unknown remains (Cañellas-Boltá et al., 2012).

The major elemental chemical compositions of nine rock samples from Aroi crater were determined at SCT-UB by XRF with a Philips PW2400 (Rh tube at $60 \mathrm{kV}$ and $125 \mathrm{~mA}$ ) using Li-tetraborate dilution. Assessments of semi-quantitative bulk mineral composition of the same powdered samples were obtained by X-ray diffraction (XRD) with a PANalytical X'Pert PRO MPD-DY 3197 diffractometer (SCT-UB).

The statistical treatment of the data was performed with R software (R Development Core Team, 2011) together with the 'vegan' package (Oksanen et al., 2006). Principal component analyses (PCA) were run to extract the main components of variability of the geochemical data (TC, TN, $\left.\delta^{13} \mathrm{C}_{\mathrm{res}}, \mathrm{Fe}, \mathrm{Ti}, \mathrm{Ca}\right)$ after standardizing and resampling with a regular spacing of $5 \mathrm{~cm}$ and omitting rows with missing values.

\section{Results}

\subsection{Facies description and macrofossil analysis}

ARO 0601 and ARO 0802 sequences were found to be predominantly radicel peats (Succow and Joosten, 2001), consisting of fine roots (diameter $<1 \mathrm{~mm}$ ) with $<10 \%$ larger remains, mainly from the Cyperaceae, Poaceae and Polygonaceae. Four facies were defined based on plant components, chemical composition, grain size, color and degree of humification (Fig. 2). Facies A (reddish peat) is composed of Cyperaceae (cf. Cyperus cyperiodes) and Polygonaceae (P. acuminatum). This facies is only present in the uppermost $6.5 \mathrm{~m}$ of the ARO 0601 sequence and the first $1.5 \mathrm{~m}$ of the ARO 0802 core. The facies is associated with very high $\mathrm{C} / \mathrm{N}$ ratios, low $\mathrm{TN}$, low
Fe and Ti values and $\delta^{13} \mathrm{C}$ values between $-21 \%$ and $-26 \%$. Facies B (Granulated muddy peat) is a brown peat composed of coarse organic fragments, mainly roots and rootlets, with low terrigenous content. This facies is present over the entire record and is characterized by high $\mathrm{C} / \mathrm{N}$ ratios, low $\mathrm{Fe}$ and Ti contents and $\delta^{13} \mathrm{C}$ values ranging from $-14 \%$ o to $-26 \%$ o (Fig. 2). A few Cyperaceae seeds are found locally in the uppermost $5 \mathrm{~m}$ of the sequence. Facies C (Organic mud) is composed of hemic and dark brown to black radicel peat (with scarce and disperse sand fraction). Seeds of cf. Axonopus paschalis (Poaceae) are more abundant in the lower part of the ARO 0601 and most of them are associated with the organic mud facies. Facies $\mathrm{C}$ was found as thin layers displaying high Fe and Ti values, high TN and relatively low $\delta^{13} \mathrm{C}$ values ( $-14 \%$ to $-22 \%$ ) and interbedding sediments of $\mathrm{Fa}$ cies B. Facies D (Sapric peat) consists of dark brown fine-grained layers with high Fe and $\mathrm{Ca}$ values. The changes among Facies B, C and $\mathrm{D}$ are gradual and transitional, whereas the intervals of Facies $\mathrm{A}$ show sharp basal limits.

\subsection{Chronology}

A total of 27 AMS ${ }^{14} \mathrm{C}$ dates were obtained from the ARO 0601 and ARO 0208 core sequences, but only 18 dates were used for the Rano Aroi sequence age model (Fig. 3). The construction of the chronological model was based on linear interpolation between dated intervals. Problems encountered in developing the model are discussed in Section 5.1.

\subsection{Geochemistry and mineralogy of the cores}

The Rano Aroi deposits are mostly organic, with TC concentrations between 40\% and 70\% (Fig. 4a). In ARO 06 01, TC values have a greater variability from $14 \mathrm{~m}$ to $9 \mathrm{~m}$ and a smaller range, with a mean value of $55 \%$ for core depths of $9 \mathrm{~m}$ to $5 \mathrm{~m}$. TN levels vary between $0.4 \%$ and $2 \%$, with $\mathrm{C} / \mathrm{N}$ ratios ranging from 40 to 110 . ARO 0802 shows similar values as core ARO 0601 with respect to TC (50-60\%), TN (0.8-2\%, peaking to $2.5 \%$ at 140 and $80 \mathrm{~cm})$ and $\mathrm{C} / \mathrm{N}(20-80$, with a marked decrease from $2 \mathrm{~m}$ upward) (Fig. 4b).

In ARO $0601, \delta{ }^{13} \mathrm{C}$ shows a constant value around $-14 \%$ from depths of $14 \mathrm{~m}$ to $9 \mathrm{~m}$, whereas from $9 \mathrm{~m}$ to $6 \mathrm{~m}, \delta^{13} \mathrm{C}$ values gradually shift from -14 to $-26 \%$ o (Fig. $4 a$ ). In the upper five meters, $\delta^{13} \mathrm{C}$ values oscillate around -26\%. In ARO 0802 , a gentle shift of $\delta^{13} \mathrm{C}$ from $-19 \%$ o to $-23 \%$ occurs from depths of $4 \mathrm{~m}$ to $3.5 \mathrm{~m}$ (Fig. $4 \mathrm{~b}$ ). $\delta^{13} \mathrm{C}_{\text {res }}$ curves show high-frequency changes (dips) within the long-term trend signal and significantly lower values for Facies $\mathrm{C}$ between 6 and $11 \mathrm{~m}$ in ARO 0601.

The XRF signal is very weak for the Rano Aroi sediments, in accordance with the high organic content. Thus, only Fe (from the Mo tube) and $\mathrm{Ti}$ and $\mathrm{Ca}$ (from the $\mathrm{Cr}$ tube) from ARO 06 had sufficient intensity (counts per second, cps) to be considered statistically significant, although also these elements have low counts ( $\mathrm{Fe}=300-700 \mathrm{cps}, \mathrm{Ca}=$ $1000-2000 \mathrm{cps}, \mathrm{Ti}=100-2000 \mathrm{cps}$ ) all along the sequence. The general trends are similar for $\mathrm{Fe}$, Ti and $\mathrm{Ca}$, although some differences are apparent when comparing $\mathrm{Fe}$ and $\mathrm{Ca}$ with Ti variability (Fig. 4a). $\mathrm{Ca}$ and $\mathrm{Fe}$ reach maximum values at $6-4 \mathrm{~m}$, coinciding with Facies D deposition. Fe and Ti, although they have very low background values, show synchronous higher values that coincide with Facies $\mathrm{C}$.

Fig. 4. (a): Main paleoenvironmental proxies analyzed in ARO 0601 core versus depth. Lithology and radiocarbon age samples are indicated in the column. Geochemical proxies: TC, TN (in percentages), $\mathrm{C} / \mathrm{N}$ ratios, and $\delta^{13} \mathrm{C}(\%)$ are indicative of the origin of organic matter. Residual values of $\delta^{13} \mathrm{C}_{\mathrm{res}}(\%)$ are used to record $\delta^{13} \mathrm{C}$ dips that are not related to long-term $C_{4}-C_{3}$ changes and caused by humidity changes or punctual variations in $C_{3} / C_{4}$ ratio Fe, Ti and $C a$ (in cps) come from terrigenous inputs together with the presence of sand grains on Facies A, B, and C, while Fe/Ti and Ca/Ti ratios are indicative of post-depositional remobilization and coincide with high values of Fe and Ca on Facies D. Macrofossil record: Seeds such as Cyperaceae (Cyperaceae sum), Poaceae (Poaceae sum) and Polygonum acuminatum. $\delta^{13} \mathrm{C}_{\mathrm{res}}$, TN, and Ti values are wet event indicators. Ca/Ti and Fe/Ti indicate oxidation and peat exposure. Periods of inferred flood and drought conditions are marked. (b): Paleoenvironmental proxies analyzed in ARO 0802 core versus depth. Lithological units and their ages are indicated in the column. Geochemical proxies: TC, TN (in percentages), C/N ratios, and $\delta^{13} \mathrm{C}(\%)$ are indicative of organic matter origin. Residual values of $\delta^{13} C_{\text {res }}(\%)$ are used to record $\delta^{13} \mathrm{C}$ dips that are not related to $\mathrm{C}_{4}-\mathrm{C}_{3}$ changes. Macrofossil record: Sand grains associated with detritic input. Seeds such as Cyperaceae (Cyperaceae sum), Poaceae (Poaceae sum) and Polygonum acuminatum. The episode characterized by heavy $\delta^{13} \mathrm{C}$ and low $\mathrm{C} / \mathrm{N}$ ratios at a depth of $1.25 \mathrm{~m}$ might indicate a basin disturbance, such as higher oxidation and opening of the surrounding vegetation. 


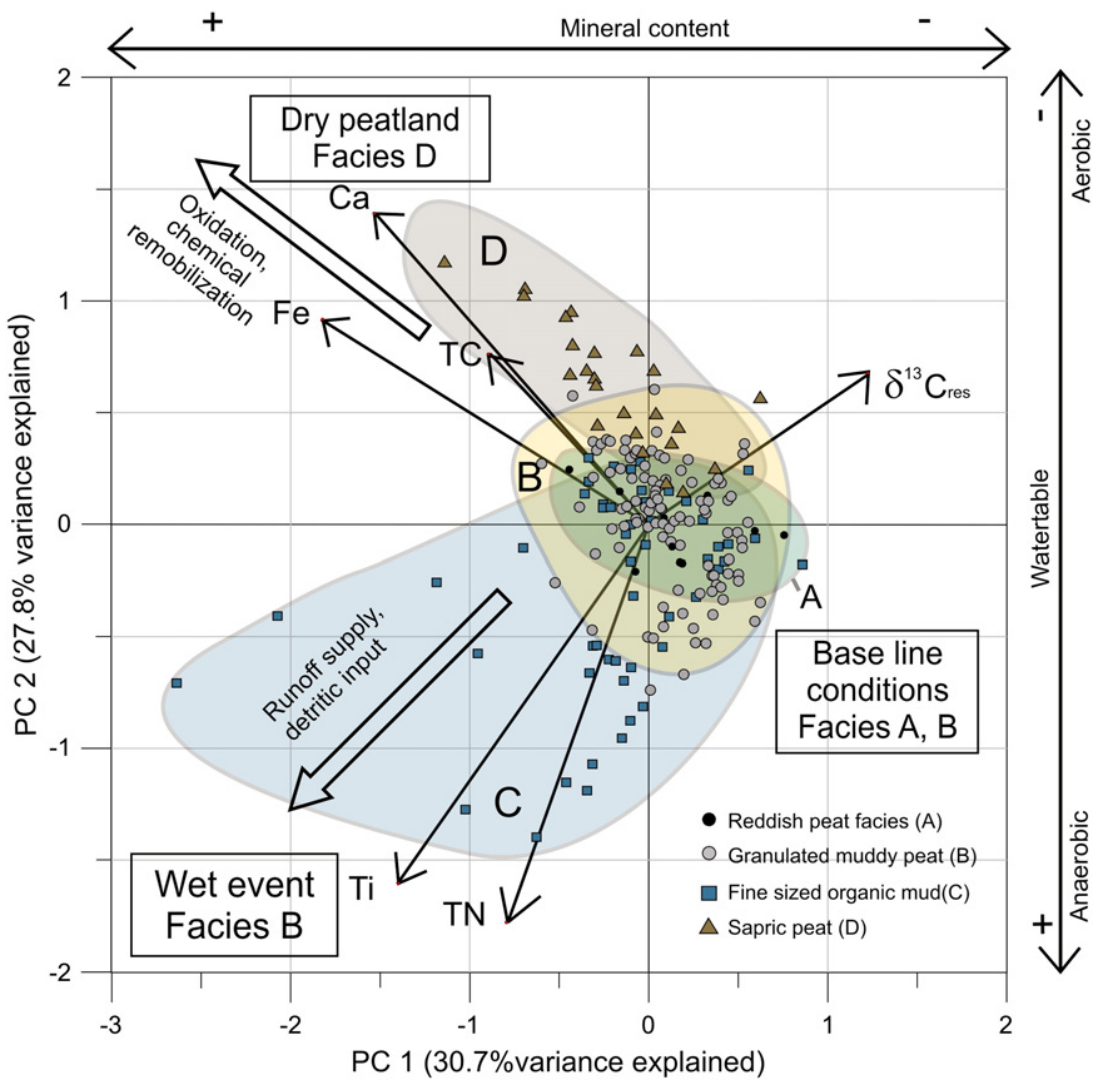

Fig. 5. Principal component analysis of the geochemical data $\left(\delta^{13} \mathrm{C}_{\mathrm{res}} \mathrm{Ti}, \mathrm{Fe}, \mathrm{Ca}, \mathrm{TN}, \mathrm{TC}, \mathrm{C} / \mathrm{N}\right.$ ). Two principal component axes explain the $60 \%$ of the variability (Axis 1 : $30.7 \%$, Axis 2 : $27.8 \%$ ). Variable loadings and sample scores are presented in the plane defined by the first two axes. To elucidate the relationship between the PCA results and the established facies, the scores are plotted following a facies color code. The diagram shows how granulated muddy peat (Facies B) and reddish peat (Facies A) lie near the axes origin and are therefore interpreted as Rano Aroi baseline conditions (termed water rise mire). Organic mud (Facies C) is associated with high Ti and TN and low $\delta^{13} C_{\text {res }}$, and are representative of flood conditions. By contrast, sapric peat (Facies D) is related to Ca, Fe and TC variability and represents exposure and oxidation of the peat surface (dry peatland stage).

Table 1

14C AMS radiocarbon age measured in pollen-enriched extract of Rano Aroi core samples. Rejected ages marked with an asterisk (see text).

\begin{tabular}{|c|c|c|c|c|}
\hline Sample name & $\begin{array}{l}\text { Depth } \\
(\mathrm{cm})\end{array}$ & Fraction dated & Dates & $\begin{array}{l}\text { Calibrated ages } \\
\text { (yr BP) }\end{array}$ \\
\hline \multicolumn{5}{|l|}{ ARO 0601} \\
\hline ARO 01-01 03 & 238 & Pollen concentrate & $2580 \pm 30^{*}$ & $2730 \pm 30^{*}$ \\
\hline ARO 01-01 20 & 255 & Pollen concentrate & $9460 \pm 50$ & $10,690 \pm 120$ \\
\hline ARO 01-01 50 & 285 & Pollen concentrate & $12,150 \pm 60$ & $13,995 \pm 153$ \\
\hline ARO 01-01 70 & 305 & Pollen concentrate & $12,880 \pm 70$ & $14,505 \pm 483$ \\
\hline ARO 01-0192 & 327 & Pollen concentrate & $13,800 \pm 60$ & $16,910 \pm 180$ \\
\hline ARO 01-01 103 & 338 & Pollen concentrate & $7440 \pm 50^{*}$ & $8270 \pm 80^{*}$ \\
\hline ARO 01-01 143 & 378 & Pollen concentrate & $26,960 \pm 150$ & $31,742 \pm 80$ \\
\hline ARO 01-02 23 & 421 & Pollen concentrate & $12,070 \pm 60^{*}$ & $13,923 \pm 138^{*}$ \\
\hline ARO 01-02 31.5 & 431.5 & Pollen concentrate & $34,000 \pm 500$ & $39,431 \pm 1051$ \\
\hline ARO 01-02 53 & 453 & Pollen concentrate & $35,300 \pm 600$ & $40,190 \pm 970$ \\
\hline ARO 01-03 57 & 552 & Pollen concentrate & $37,600 \pm 600$ & $42,210 \pm 520$ \\
\hline ARO 01-04 62 & 662 & Pollen concentrate & $33,900 \pm 500^{*}$ & $39,310 \pm 2570^{*}$ \\
\hline ARO 01-05 67 & 760 & Pollen concentrate & $45,000 \pm 2000$ & $48,710 \pm 2570$ \\
\hline ARO 01-06 72 & 872 & Pollen concentrate & $49,000 \pm 3000$ & $54,600 \pm 5000$ \\
\hline ARO 01-07 83 & 979 & Pollen concentrate & $52,000 \pm 4000$ & $57,339.09$ \\
\hline ARO 01-08 83 & 1083 & Pollen concentrate & $>50,000$ & $60,843.14$ \\
\hline ARO 01-09 88 & 1181 & Pollen concentrate & $53,000 \pm 4000$ & $64,145.02$ \\
\hline ARO 01-10 88 & 1288 & Pollen concentrate & $>49,000$ & $67,750.15$ \\
\hline ARO 01-11 88 & 1380 & Pollen concentrate & $49,000 \pm 3000$ & $70,849.88$ \\
\hline \multicolumn{5}{|l|}{ ARO 0802} \\
\hline ARO 02-02 35 & 85 & Pollen concentrate & $270 \pm 30$ & $307 \pm 25$ \\
\hline ARO 02-03 25 & 125 & Pollen concentrate & $1050 \pm 30$ & $965 \pm 41$ \\
\hline ARO 02-04 25 & 175 & Pollen concentrate & $2265 \pm 30$ & $2206 \pm 48$ \\
\hline ARO 02-04 44 & 194 & Pollen concentrate & $5070 \pm 40$ & $5820 \pm 92$ \\
\hline ARO 02-05 25 & 225 & Pollen concentrate & $9180 \pm 50$ & $10,339 \pm 100$ \\
\hline ARO 02-06 31 & 281 & Pollen concentrate & $12,420 \pm 60$ & $14,501 \pm 350$ \\
\hline ARO 02-07 25 & 325 & Pollen concentrate & $13,880 \pm 70$ & $14,921 \pm 100$ \\
\hline ARO 02-08 25 & 375 & Pollen concentrate & $30,300 \pm 300$ & $34,475 \pm 232$ \\
\hline
\end{tabular}


SEM analysis of Facies $C$ sand grains revealed the presence of plagioclase and quartz grains in the coarse $(>500 \mu \mathrm{m})$ and of rutile, quartz and $\mathrm{Mn}$ oxide grains in the fine fractions $(<500 \mu \mathrm{m})$. SEM analysis of the Facies $\mathrm{D}$ (Sapric peat) showed that minerals consist of Fe, Mn oxides and organic bounded Ca. Facies A and B had insufficient mineral contents for SEM analysis.

\subsection{Watershed rock analyses (mineralogy and geochemistry)}

To investigate the inorganic fraction of sediment material that has been delivered to the Rano Aroi mire, the mineralogical and geochemical composition of selected volcanic rock samples from the watershed was analyzed. XRF analysis of bulk samples showed that $\mathrm{SiO}_{2}$ is the most abundant oxide, followed by $\mathrm{Fe}, \mathrm{Al}$ and $\mathrm{Ca}$ oxides (Table 2a). $\mathrm{Na}$, $\mathrm{Mg}$ and Ti oxides are present in concentrations of 3-4 wt.\%, while Mn, $\mathrm{P}$ and $\mathrm{K}$ oxide concentrations remain below $1 \%$. Very high levels of $\mathrm{Fe}$ and $\mathrm{Ti}$ in the Rano Aroi catchment have been documented by previous petrographic studies (Baker et al., 1974). XRD analysis showed that most rocks are composed of Ca-plagioclase and pyroxenes (enstatitediopside). Ilmenite and quartz minerals are frequently present, and Na-felspathoids, spinel, olivine and rutile are present in significant concentrations (Table $2 \mathrm{~b}$ ). These results indicate that rocks in the catchment range from basalts to tholeites-hawaiites.

\subsection{Geochemical variability of the peat record}

Principal Component Analysis (PCA) of 6 variables (TN, TC, $\delta^{13} \mathrm{C}_{\mathrm{res}}$, $\mathrm{Ti}, \mathrm{Fe}$, and $\mathrm{Ca}$ ) and 200 samples (Fig. 5) shows that the first component explains $30.7 \%$ of the total variance, whereas the second component explains an additional 27.8\%. Ti, $\mathrm{Fe}$ and $\mathrm{Ca}$ contributed negatively to the first component, while $\delta^{13} \mathrm{C}_{\text {res }}$ values were found at the opposite end. TN and Ti tied the negative end of $\mathrm{PC2}$, while $\mathrm{Ca}, \mathrm{Fe}, \mathrm{TC}$ and $\delta^{13} \mathrm{C}_{\text {res }}$ contributed positively to PC2. The reddish peat (Facies A) and granulated muddy peat (Facies B) showed sample scores at the center of the PCA biplot (Fig. 5). By contrast, the scores of organic mud (Facies $\mathrm{C}$ ) are related to $\mathrm{Ti}, \mathrm{TN}$ and to lesser extent to $\delta^{13} C_{\text {res }}$, while Sapric peat (Facies D) follows Ca, Fe and TC.

\section{Discussion}

\subsection{Chronology}

The ages that were found for the Facies A reddish peat in the uppermost part of ARO 0601 were systematically too young. On the $\mathrm{X}$-ray radiographs (not shown), this facies shows less compaction and horizontal structures, suggesting it represents fresh Cyperaceae (Scirpus sp.) peat mats that are composed of roots, rootlets and rhizomes. Plant remains and macrofossil composition of Facies A are similar to the structure of the buoyant mats that are currently present in Raraku and Kau lakes. Similarly, Rano Aroi may have had similar, partially buoyant peat patches during episodes with high water table, allowing simultaneous top down peat growth in floating mats and debris aggregation at the lake bottom. Floating vegetation dynamics can cause peat mats to invert or flip over, as documented for Rano Kau (Butler et al., 2004). The growth pattern, presence of roots and rhizomes and inversion dynamics could be responsible for the previously described anomalous dating (Peteet et al., 2003; Butler et al., 2004). Moreover, if these (too young) ages are used to establish age-depth relationships between the ARO 0601 and ARO 0802 cores, the steep slope of the peat deposits would be inconsistent with the peat accumulation pattern of a kettle hole or a percolation mire (see Section 5.2; Gaudig et al., 2006). From $8.5 \mathrm{~m}$ to the bottom of ARO 06 01, radiocarbon dating shows ages older than $50 \mathrm{kyr}$ BP (Table 1, Fig. 3), i.e. beyond the radiocarbon detection limit. As the accumulation rate between 40 and $48 \mathrm{cal}$ kyr BP (3.7-7.6 m), based on four dates, is constant and the peat facies are the same until the base of the sequence, it can be assumed that sedimentation rates also have been the same. Consequently, the lower part of the core, was dated by linear extrapolating as $70 \mathrm{kyr}$ old (Table 1, Fig. 3).

Accumulation rates vary from 0.02 to $1 \mathrm{~mm} / \mathrm{year}$, which are common rates for peats worldwide (Couwenberg et al., 2001; Dommain et al., 2011). The mean accumulation rate from 13.90 to $4.31 \mathrm{~m}$ depth is $0.3 \mathrm{~mm} /$ year. Dates at $4.31 \mathrm{~m}$ and $3.78 \mathrm{~m}$ are approx. $39 \mathrm{cal} \mathrm{kyr} \mathrm{BP}$ and approx. $31 \mathrm{cal}$ kyr BP, respectively. The consequent very low accumulation rate is reflected in a sharp unconformity at $4.31 \mathrm{~cm}$, where highly oxidized peat (Facies D) is covered by low humified peat (Facies A). Peat facies analysis (see Section 5.2) suggests that during this time interval the wetland suffered from drought and erosion (see Section 5.2). Peat accumulation must have started again soon after, as downward extrapolation of the very low accumulation rates between approx. 31 and $17.5 \mathrm{cal} \mathrm{kyr} \mathrm{BP}(0.03 \mathrm{~mm} / \mathrm{year})$ indicate. This extrapolation also shows that - probably at the start of resuming peat accumulation - accumulation rates must have been somewhat larger, possibly coincident with the initial peak in the Chilean humidity index until 37 cal kyr BP. After approx. 14-15 cal kyr BP accumulation rates increase again in both ARO 0601 and ARO 08 02. The mid-to-late Holocene (5-2.5 cal kyr BP) is characterized by very low accumulation rates in ARO 08 02; the rates rise again during the last 2.5 cal kyr BP up to the present time.

\subsection{Origin of organic matter in the cores}

As diagenetic shifts in carbon isotopes values over the millennial time scale are generally much lower than source differences (Talbot and Johannessen, 1992), $\delta^{13} \mathrm{C}$ may be used to distinguish between remains from plants with $C_{3}$ and $C_{4}$ metabolic pathways of photosynthesis (Talbot and Johannessen, 1992; Meyers, 1994). Significant methanogenesis as the single source of significant fractionation in peat (Talbot and Johannessen, 1992; Meyers, 1994) is improbable because no correlation exists between $\delta^{13} \mathrm{C}$ and $\mathrm{C} / \mathrm{N}$ changes, and $\delta^{13} \mathrm{C}$

Table 2a

Bulk geochemistry from XRF expressed as major oxides $(\%(m / m))$ (XRF data).

\begin{tabular}{|c|c|c|c|c|c|c|c|c|c|c|}
\hline \multirow[t]{2}{*}{ Sample name } & $\mathrm{Fe}_{2} \mathrm{O}_{3}$ & $\mathrm{MnO}$ & $\underline{\mathrm{TiO}_{2}}$ & $\mathrm{CaO}$ & $\mathrm{K}_{2} \mathrm{O}$ & $\underline{\mathrm{P}_{2} \mathrm{O}_{5}}$ & $\mathrm{SiO}_{2}$ & $\mathrm{Al}_{2} \mathrm{O}_{3}$ & $\mathrm{MgO}$ & $\mathrm{Na}_{2} \mathrm{O}$ \\
\hline & $\mathrm{Fe}_{5}$ & $\mathrm{Mn}_{3}$ & $\mathrm{Ti}_{4}$ & $\mathrm{Ca}_{3}$ & $\mathrm{~K}_{3}$ & $\mathrm{P}_{3}$ & $\mathrm{Si}_{3}$ & $\mathrm{Al}_{3}$ & $\mathrm{Mg}_{3}$ & $\mathrm{Na}_{7}$ \\
\hline 1 & 13.09 & 0.18 & 3.18 & 9.98 & 0.54 & 0.41 & 48.78 & 16.01 & 3.81 & 3.06 \\
\hline 2 & 11.75 & 0.16 & 2.73 & 10.04 & 0.47 & 0.4 & 47.75 & 17.09 & 4.18 & 3.04 \\
\hline 3 & 12.88 & 0.16 & 3.20 & 9.63 & 0.7 & 0.43 & 48.38 & 15.34 & 4.09 & 3.08 \\
\hline 4 & 17.92 & 0.25 & 4.13 & 7.39 & 0.38 & 0.47 & 41.96 & 15.69 & 4.8 & 2.32 \\
\hline 5 & 13.2 & 0.17 & 3.17 & 9.42 & 0.4 & 0.43 & 46.07 & 15.83 & 3.88 & 2.91 \\
\hline 6 & 18.54 & 0.18 & 4.95 & 3.72 & 0.4 & 0.56 & 28.71 & 20.91 & 3.69 & 0.59 \\
\hline 7 & 14.44 & 0.21 & 3.61 & 5.09 & 0.69 & 0.44 & 38.58 & 18.96 & 4.2 & 1.5 \\
\hline 8 & 13.75 & 0.19 & 3.34 & 7.42 & 0.76 & 0.41 & 45.71 & 17.85 & 3.71 & 2.55 \\
\hline 9 & 12.87 & 0.16 & 3.55 & 8.88 & 0.69 & 0.47 & 48.22 & 14.15 & 4.29 & 3.04 \\
\hline
\end{tabular}


Table 2b

Mineral assemblage of rock samples expressed as estimated \%m/m (XRD-data).

\begin{tabular}{|c|c|c|c|c|c|c|c|c|}
\hline Sample & Ca-plag. & Pyx (enst.-diop.) & Ilmenite & Qtz & Foid. (sodalite) & Spinel & Oliv. (forst.) & Rutile \\
\hline 1 & 80 & 17 & 3 & - & - & - & - & - \\
\hline 2 & 75 & 21 & 1 & 3 & - & - & - & - \\
\hline 3 & 82 & 11 & 2 & 3 & 1 & 1 & - & - \\
\hline 4 & 69 & 18 & 4 & - & - & - & 9 & - \\
\hline 5 & 67 & 26 & 2 & - & - & - & 5 & - \\
\hline 6 & 39 & 47 & 9 & - & - & 5 & - & - \\
\hline 7 & 49 & 34 & 5 & - & - & - & 11 & 1 \\
\hline 8 & 83 & 14 & - & - & 3 & - & - & - \\
\hline 9 & 75 & 23 & 2 & - & - & - & - & - \\
\hline
\end{tabular}

values are within the natural limits of changes between $C_{3}$ to $C_{4}$ land plants. From 70 to $55 \mathrm{kyr} \mathrm{BP}$, the $\delta^{13} \mathrm{C}$ values of ARO 0601 indicate the predominance of $\mathrm{C}_{4}$-type plant remains. A gradual transition from $\mathrm{C}_{4}$ to $\mathrm{C}_{3}$ plant remains is reflected by progressively lower values of $\delta^{13} \mathrm{C}$, reaching $-26 \%$ at approximately $47 \mathrm{cal} \mathrm{kyr} \mathrm{BP}$. The uppermost part of the record shows low values of $\delta^{13} \mathrm{C}(-26 \%)$, which suggests that the mire from that time on until the present time has been dominated by $C_{3}$ plants. This interpretation is supported by the presence of seeds of the $C_{4}$ grass species A. paschalis from 70 to $47 \mathrm{cal}$ kyr BP, whereas seeds of $C_{3}$ plants, including $S$. californicus, cf. $C$. cyperoides and $P$. acuminatum, were found in the uppermost part of the sequence. The same unidirectional succession from $C_{4}$ to $C_{3}$ plants is described for the same depth in palynological studies (Flenley and King, 1984; Flenley et al., 1991) of a core (ARO 01) from the center of the mire.

High-frequency oscillations of relatively low $\delta^{13} \mathrm{C}$ values, coinciding with $\mathrm{Fe}$ and Ti peaks in organic mud (Facies $\mathrm{C}$ ) stand out from this general trend. In addition to differences in metabolic pathways of peat-forming vegetation, $\delta^{13} \mathrm{C}$ can provide information on changes in productivity and environmental conditions, such as insolation or humidity (Hong et al., 2001). In the stage dominated by $\mathrm{C}_{4}$ plants, $\delta^{13} \mathrm{C}$ peaks with lower values can be interpreted as a higher contribution of algal and $C_{3}$ plant organic matter, both of which are favored by wetter conditions. At the same time, $C_{3}$ plant fractionation is sensitive to humidity and precipitation, as shown in isotope measurements on cellulose and macrofossils on peatland records (Aucour et al., 1999;
Hong et al., 2001). Higher levels of precipitation and soil moisture and a closer canopy result in lower $\delta^{13} \mathrm{C}$ values in $C_{3}$ plants and vice versa (Aucour et al., 1999; Hong et al., 2001; Muller, 2006).

\subsection{Facies interpretation and mire development}

\subsubsection{Mire development}

Rano Aroi mire currently receives water from a perched aquifer with low permeability that is located to the north and loses water to surface outflow and infiltration toward the south (Herrera and Custodio, 2008). This hydrological configuration indicates that Rano Aroi is a self-sealing mire (sensu Joosten and Clarke, 2002), fed by discharging deeper groundwater (similarly to percolation mires) and not by interflow, and easily affected by changes in precipitation (similar to kettle hole mires). Moreover, the small basin reception volume amplifies rainfall sensitivity. Although we did not recover the oldest sediments deposited in the basin, it is likely that Rano Aroi evolved from a formerly dry basin into a very wet mire (Facies B) that was regularly flooded (Facies C). As the mighty peat deposits and the identical age-depth curves of both ARO 0601 and ARO 0802 indicate, the water level must have steadily risen, probably as a result of formation of stagnating layers on increasingly higher levels (cf. Gaudig et al., 2006). Earlier stages of this process, which is typical for kettle hole mires (Joosten and Clarke, 2002) can be observed in other small craters on the island.

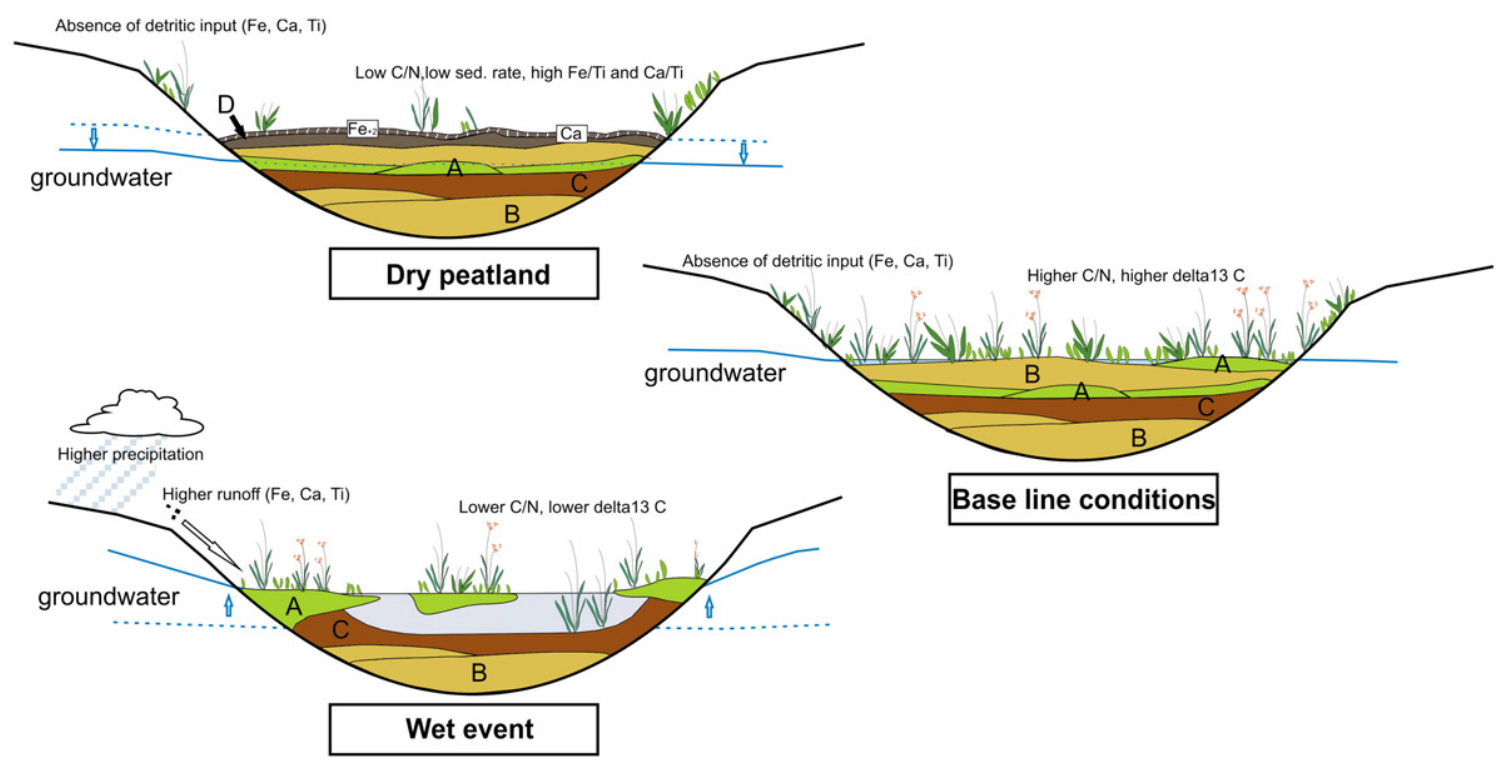

Fig. 6. Mire accumulation facies model by different water level stages. This model is based on the PCA analysis of the geochemical characteristics of facies (Fig. 5). Three stages of water level have been differentiated. The wet events stage entails a flooded area where fine-sized organic mud facies is deposited. High values of Ti, Fe and Ca are recorded due to increased runoff produced by more intense precipitation. Water rise mire is a stage that is representative of Rano Aroi baseline conditions and was dominant for the last 70 kyr BP: granulated peat facies are formed from the continuous accumulation of organic matter that is mainly composed of sedge and grass roots. The dry peatland stage occurs when water restriction leave the mire in a negative hydric balance. Surface peat is mineralized, and Fe and Ca are concentrated at the uppermost levels. 


\subsubsection{Principal Component Analysis (PCA)}

The main geochemical processes that controlled depositional development are illustrated in the PCA plot (Fig. 5) that shows that the negative end of first component (PC1) is tied by $\mathrm{Ca}, \mathrm{Fe}$ and $\mathrm{Ti}$, which have a lithogenic origin. These elements would have originated from the weathering volcanic rocks in the Rano Aroi catchment (Section 4.4), which are rich in Ca-plagioclase, pyroxenes, ilmenite and rutile (Tables $2 \mathrm{a}$ and $2 \mathrm{~b}$ ). This link suggests that $\mathrm{PC} 1$ primarily responds to the presence of terrigenous components that have been brought to the mire by runoff and incorporated into the peat as particulate sediment.

The second component (PC2) of the PCA clearly displays that the chemical behavior of $\mathrm{Ca}$ and $\mathrm{Fe}$ (positive end of PC2) differs from that of $\mathrm{Ti}$ (negative end of PC2), although all three elements have been incorporated into the mire as terrigenous particles. In organic soils, $\mathrm{Ca}$ and $\mathrm{Fe}$ contents are not only related to primary input, but can be also caused by post-depositional remobilization. To check this hypothesis, the $\mathrm{Ca}$ and Fe data were normalized to Ti, which is considered to be immobile in peat (Weiss et al., 2002; Muller et al., 2006, 2008). The extremely high $\mathrm{Ca} / \mathrm{Ti}$ and $\mathrm{Fe} / \mathrm{Ti}$ ratios between 4 and $6 \mathrm{~m}$ depth resemble the enrichment levels that are found in peat profiles on the fen-to-bog transition, indicating the change from geogenous (fen) to ombrotrophic (bog) conditions (Gorham and Janssens, 2005). High $\mathrm{Fe} / \mathrm{Ti}$ ratios can be attributed to $\mathrm{Fe}^{2+}$ migrating upward from the anaerobic peat below followed by precipitation as $\mathrm{Fe}^{3+}$ oxide in the upper aerated peats. Through this process $\mathrm{Fe}$ in ombrotrophic peat profiles accumulates in the zone of water table fluctuations (Damman et al., 1992). The distribution of Ca in ombrotrophic mires has been related to bioaccumulation in the biologically active zone (Damman et al., 1992; Shotyk, 1996; Shotyk et al., 2001). Similar high values have been observed in the ombrotrophic phase (8.2 to $4.9 \mathrm{cal} \mathrm{kyr} \mathrm{BP}$ ) of Raraku Lake sediments (Sáez et al., 2009). Negative PC1 but positive PC2 values can then be related to $\mathrm{Fe}$ and $\mathrm{Ca}$ complexation with organic matter, i.e. when a lowering water table leads to oxic conditions in the peat. Negative PC1 (higher Ca, Fe, Ti) and negative PC2 (no oxidation) with high TN and lower $\delta^{13} C_{\text {res }}$, in contrast, can be explained by a higher water table and higher detrital input. In consequence, we interpret PC2 as being indicative of changes in water table level and redox conditions.

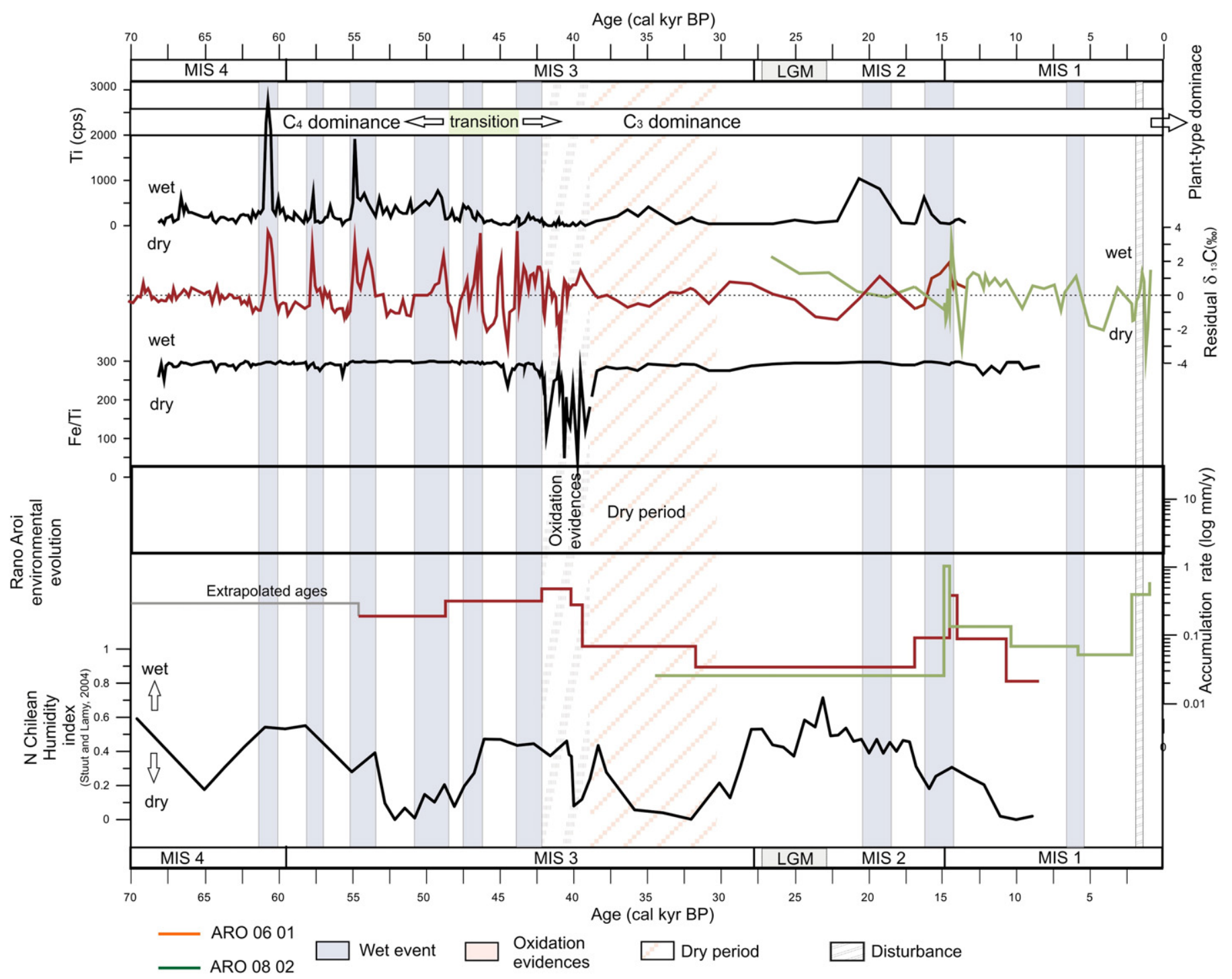

Fig. 7. Synthesis of Rano Aroi environmental mire evolution. Wet episodes are defined from Ti cps and $\delta^{13} \mathrm{C}$ residual values. Very high Fe/Ti ratios are indicative of the exposure and oxidation of the peat sometime after $40 \mathrm{cal}$ kyr BP, and low sedimentation rates indicate no deposition and possible erosion between $38 \mathrm{cal}$ kyr BP and $17 \mathrm{cal}$ kyr BP. Another episode with a very low accumulation rate is defined during the mid-Holocene. A possible anthropogenic disturbance is inferred from $\delta^{13} \mathrm{C}$ and $\mathrm{C} / \mathrm{N}$ ratio variations and defined as 750-850 AD. The North Chilean humidity index, obtained from grain-size analyses in marine core GeoB3375 (27 ${ }^{\circ}$ ) according to Stuut and Lamy (2004), is plotted for comparison. 
5.3.3. The three main environmental and hydrologic conditions of Rano Aroi In the development of Rano Aroi three main environmental and hydrologic settings can be distinguish on the basis of the Principal Component Analysis and the characterization of the four facies (Fig. 6):

a) Flooded mire (Facies $C$ ). In the PCA, the Facies $C$ samples are directly tied to the TN and Ti loadings (negative PC1 and PC2), i.e. to a high content of lithogenic elements and a high water table. Facies C might represent an open water phase (as terrigenous material would not have been transported through dense mire vegetation), when suspended material could be transported to the center of the mire during periods of precipitation (Fig. 6). The lower $\delta^{13} \mathrm{C}_{\text {res }}$ isotopic values are in accordance with organic matter that originated in conditions of higher soil moisture or precipitation (Muller, 2006; Hong et al., 2001, see Section 5.2). The lower isotopic values could, however, also result from the increasing presence of $\mathrm{C} 3$ plants, and therefore point at a change in vegetation during wet events. The abundant roots and rootlets that cross-cut the Facies C layers would have penetrated the lake sediments from above in subsequent mire phases (displacement peat, Weber, 1930).

b) Dry mire (Facies $D$ ). The dark color and fine grain size demonstrate advanced humification of the Facies D sapric peat. Facies D scores are directly related to Fe and Ca loadings (negative PC1, positive PC2) which can be interpreted as oxidized peat. These chemical and morphological features suggest that Facies D reflects long-term drought phases likely entailing strong decomposition (Fig. 6). The accumulation rates that - in spite of apparent stronger mineralization are similarly high as before (Fig. 3) indicate that these drier conditions were associated with higher vegetation productivity.

c) Baseline mire conditions (Facies B and A). The brown-reddish peats of Facies B and A are mainly composed of roots, rootlets and other macroremains of sedges and herbs with constant $\delta^{13} \mathrm{C}_{\text {res }}$ and high $\mathrm{C} / \mathrm{N}$ ratios. Facies $\mathrm{A}$ is better preserved and has a lower degree of humidification than Facies B, likely due to more constant water tables and faster burial. Facies A and B are interpreted as being deposited in a kettle-hole mire (Joosten and Clarke, 2002), similar to the present Rano Aroi conditions, in which long-term stable water tables near the surface allow for the constant accumulation of low-decomposition peat with very restricted terrigenous input (Fig. 6). The scores of Facies A and B samples show very low variability on the first two PCA components (Fig. 5). They illustrate the more stable baseline conditions that are interrupted by wetter phases of allochtonous sediment delivery (Facies C) or drier phases with stronger decomposition (Facies D).

\subsection{Environmental changes}

The facies model and geochemical and paleo-ecological data allow us to interpret the development of the Rano Aroi mire in terms of depositional and paleo-hydrological changes during the last $70 \mathrm{kyr}$. Mire development is strongly controlled by temperature and humidity, which permit us to reconstruct the Late Pleistocene regional paleoclimate on Easter Island (Fig. 7).

\subsubsection{MIS 4 (70-60 kyr BP in Rano Aroi)}

The homogenous sequence of Facies B during the MIS 4 stadial shows that Rano Aroi was in its base-line state when in the $C_{4}$ grass-dominated kettle-hole mire accumulation rates were reached of approximately $0.3 \mathrm{~mm} / \mathrm{year}$. The MIS 4 stadial is regionally characterized by low southern Pacific SST temperatures (Kaiser et al., 2005). Wind circulation around Antarctica was intensified, and the northward migration of the Westerlies and the Antarctic Circumpolar Current (ACC) brought sub-Antarctic cold waters up to temperate latitudes (Kaiser et al., 2005). Simultaneously, a southward shift of the ITCZ resulted in enhanced precipitation over Brazil (Wang et al., 2007), while a dry period was recorded in the Northern Hemisphere, such as in Eastern China (Wang et al., 2007) and the Central American Pacific coast (Leduc et al., 2007). This climatic configuration involved a shrinking SPA and a favorable pattern for regular precipitation at Easter Island, caused by the eastward expansion of the SPCZ. The constant water supply will have favored peat accumulation in the sheltered basin. At the end of MIS 4 the first abrupt wet event of the record occurred.

\subsubsection{MIS 3 (60-27.8 cal kyr)}

Two different MIS 3 states (Early and Late) can be distinguished in Rano Aroi. The first phase from ca. 60 to 42 cal kyr BP is characterized by short and abrupt events of higher sediment delivery, which implies the establishment of moister conditions on Easter Island (Fig. 7). The millennial-scale range of these events is coherent with climatic instability and temperature and humidity suborbital cycles that were globally identified for MIS 3 (Baker et al., 2001; Haug et al., 2001; Oppo et al., 2003; Wang et al., 2004, 2007; Muller, 2006; Clement and Peterson, 2008). Antarctic records show millennial-scale warming events that were simultaneous with drops in temperature in the north Atlantic region (Heinrich events), configuring an interhemispheric teleconnection known as the "bipolar seesaw" (Blunier and Brook, 2001). Many studies note the coincidence of millennial-scale cycles of SST, humidity and marine productivity in the tropical Atlantic and Pacific Oceans and cooling episodes in the Northern Hemisphere and Greenland (Baker et al., 2001; Haug et al., 2001; Oppo et al., 2003; Wang et al., 2004, 2007; Muller, 2006; Clement and Peterson, 2008). Several mechanisms have been proposed to explain these teleconnections, including thermohaline circulation (THC) variability, sea ice feedbacks and changes in convection or movement of the Intertropical Convergence Zone (ITCZ) (Clement and Peterson, 2008). Southern displacements of the ITCZ and the SPCZ together with intensification of the Southern Westerlies result in a regional configuration that favors the occurrence of higher moisture and storminess on Easter Island (Wang et al., 2004; Muller, 2006). Such moister conditions, which affect most of the south Pacific region (Lamy et al., 1998; Stuut and Lamy, 2004), could have been responsible for the Rano Aroi wet events. Records from the central Coast of Chile (Lamy et al., 1998; Stuut and Lamy, 2004) prove the importance of precession cycles over the SW Storm Track position and show the occurrence of a wet period from 50 to $40 \mathrm{cal} \mathrm{kyr} \mathrm{BP.}$

The Late MIS 3 is characterized by geochemical evidence (high Ca/ $\mathrm{Ti}$ and $\mathrm{Fe}$ /Ti ratios) of peat oxidation which allow us to identify an ancient exposure surface dated at $39.5 \mathrm{cal}$ kyr BP. Peat is highly effectively lost by oxidation with a rate of up to few $\mathrm{cm}$ per year (Couwenberg et al., 2001). This oxidation event must have happened between 39 and $31 \mathrm{cal} \mathrm{kyr}$, resulting in a failing to record environmental changes during and before the event. The age-depth curve and the reconstructed accumulation rates (par. 5.1) indicate that exposure has only been short lasting and peat accumulation restarted rather quickly, be it with a (very) low accumulation rate. Conditions between 39 and 31 cal kyr BP were probably dry and relatively cold in Easter Island as also observed in South American continent records where a dry period was identified between 37 and 31 cal kyr BP (Lamy et al., 1998; Stuut and Lamy, 2004, Fig. 7). Rano Aroi record shows very low accumulation rates during Late MIS 3 (31 to 27.8 cal kyr BP) possibly due to low temperatures that hampered the growth of the mire. These low temperatures would have lasted until the end of MIS 2 (Sáez et al., 2009).

Overlaid with this wet-dry variability, Rano Aroi deposits record a change in the prevalence of $C_{4}$ to $C_{3}$ plants over the period from 50 to $45 \mathrm{cal}$ kyr BP. To some extent, this process is supported by pollen studies published by Flenley et al. (1991) indicating dominance of $C_{4}$ plants until 50 cal kyr BP, then shifting to a $C_{3}$ dominance. In ARO 06 01, at 45 cal kyr $\mathrm{BP}$, extremely well-preserved plant remains, including S. californicus rhizomes, were found in peat with very high $\mathrm{C} / \mathrm{N}$ values. These rhizomes represent the oldest $S$. californicus remains that have been found to date on the island. Changes in the ratio of $C_{3} / C_{4}$ plants are generally associated with climate changes (Talbot and Johannessen, 1992; Street-Perrott et al., 
1997; Huang et al., 1999; Meyers and Terranes, 2001; Street-Perrott et al., 2004), with low concentrations of atmospheric $\mathrm{CO}_{2}$, low temperatures and restricted water supply being the major selective forces for the dominance of $C_{4}$ over $C_{3}$ (Street-Perrott et al., 1997; Huang et al., 1999; Ehleringer et al., 1997).

In the case of Rano Aroi, vegetation succession toward a dominance of $C_{3}$ plants could reflect the expansion of $C_{3}$ sedge species as a response a) to milder temperatures and globally higher atmospheric $\mathrm{CO}_{2}$ concentration and $\mathrm{b}$ ) to the progressive increase of humidity since the beginning of MIS 3 as indicated by the occurrence of abrupt wet events. At Rano Aroi, the changing $\mathrm{C}_{4}$-to- $\mathrm{C}_{3}$ signal can, however, also be ascribed to the arrival and expansion of $S$. californicus on the island. The arrival of this species, which originates from the South American continent, is attributed to wind or bird transport (Heiser, 1974), with both vectors having a possible climatic and a substantial stochastic component.

\subsubsection{Early MIS 2 and Last Glacial Maximum (LGM) (27.8-19 cal kyr} BP)

The lowest peat accumulation rates at Rano Aroi were recorded between 27.8 and $17.5 \mathrm{cal} \mathrm{kyr} \mathrm{BP} \mathrm{(0.03} \mathrm{mm/year,} \mathrm{Fig.} \mathrm{7).} \mathrm{This} \mathrm{finding}$ likely reflects low temperatures hampering the normal growth of the plant species in the mire at that time. Previous studies from the Raraku site attribute humid and cold conditions to the island during the LGM (Azizi and Flenley, 2008; Sáez et al., 2009). The reconstructed high water table of Raraku Lake suggests substantial rainfall coupled with low evaporation. However, pollen data from Azizi and Flenley (2008) suggest that cold temperature was the main factor controlling forest development on Easter Island during glacial periods. During MIS 2, global temperatures reached a minimum between 19 and $22 \mathrm{cal} \mathrm{kyr}$ BP (Heusser and Heusser, 2006; Lea et al., 2006; Kaiser et al., 2008), and the northward migration of the Westerlies storm track caused the arrival of colder waters to intermediate latitudes (Lamy et al., 1998; Pena et al., 2008). It is therefore likely that temperature was the driving factor for the low accumulation rates at Rano Aroi during that period.

\subsubsection{Late glacial (19-11.7 cal kyr BP)}

Rano Aroi provides evidence of a warmer climate at $17.5 \mathrm{cal}$ kyr BP, when peat accumulation accelerated. A high water table event was recorded at 15 cal kyr BP (Fig. 7), followed by an episode of very high peat accumulation from 15 to 14 cal kyr BP ( $1 \mathrm{~mm} /$ year, Fig. 7). This period is characterized by a high concentration of $P$. acuminatum seeds, a pioneer species that is commonly found in the first stages of succession. Marine records from the central Pacific region show that deglaciation warming started approximately $19 \mathrm{cal}$ kyr BP, parallel to the retreat of the Antarctic sea ice (Kaiser et al., 2008) and appreciably earlier than the continental response (Sáez et al., 2009). This warming has been related to phases of low precession and high obliquity (Pena et al., 2008), which drove storm tracks southward and enhanced the E-W Pacific thermal gradient, favoring La Niña-like conditions (Koutavas et al., 2002; Pena et al., 2008).

Studies of the Raraku Lake record describe the Easter Island hydrological and vegetational response to deglaciation at $17.3 \mathrm{cal}$ kyr BP, in accordance with South American and New Zealand continental records (Sáez et al., 2009). Maximum accumulation (14 cal kyr BP) coincides with the highest rates of sea level rise during the last deglaciation period as a response to Melt Water Pulse A1 (Hanebuth et al., 2000; Dickinson, 2001; Lambeck and Chappell, 2001). Sea level rise together with warmer SST, might have played an important role in the development of enhanced convection storms.

\subsubsection{Holocene (11.7-2.5 cal kyr BP)}

During the Early Holocene, the accumulation rate at Rano Aroi was low (0.1 mm/year) (Fig. 7). Raraku Lake underwent a gradual drop in water level, leading to the establishment of a shallow swamp system from 11 to 5.5 cal kyr BP (Sáez et al., 2009). From a regional perspective, the early Holocene is according to several southern hemispheric records (Pena et al., 2008) characterized by a warming trend. Pacific SST were maximal at approximately $12 \mathrm{cal}$ kyr BP and generally decreased thereafter, until modern SST were reached (Kaiser et al., 2005; Kaiser et al., 2008). Arid conditions during the early Holocene occurred in Central Chile (Moreno and León, 2003; Paduano et al., 2003; Tapia et al., 2003; Valero-Garcés et al., 2005) and lasted until approximately 5-4 cal kyr BP.

The dominant dry conditions were interrupted by a short-term flood episode at $5.8 \mathrm{cal} \mathrm{kyr} \mathrm{BP} \mathrm{in} \mathrm{Aroi} \mathrm{and} \mathrm{between} 6.2$ and $5.8 \mathrm{cal} \mathrm{kyr}$ BP in Raraku (Sáez et al., 2009). This wet period on Easter Island is synchronous with the global climatic event between 6 and $5 \mathrm{cal}$ kyr BP (Mayewski et al., 2004), the enhanced precipitation period from 6 to 5.8 cal kyr BP on the Galápagos Islands (Conroy et al., 2008) and stronger SW activity in Southern Chile (Heirman, 2011).

Dry conditions on Easter Island lasted until the Late Holocene. Low lake level conditions caused a sedimentary hiatus in the center of Raraku Lake from 4.2 to 0.8 cal kyr BP (Mann et al., 2008; Sáez et al., 2009) and a shorter period in the eastern lake margin (Cañellas-Boltà et al., work in progress), while in Rano Aroi, the 5.5-2.5 cal kyr BP period is characterized by very low accumulation rates $(0.06 \mathrm{~mm} / \mathrm{year})$.

\subsubsection{Late Holocene (2.5 cal kyr BP to present)}

The Rano Aroi record shows that Late Holocene wetter conditions began on Easter Island approx. 2.5 cal kyr BP, coinciding with wetter conditions in mid-latitude Chile (van Geel et al., 2000) and Antarctica warming due to increased southern summer insolation (Ingolfsson et al., 1998). The timing of this transition lags that of eastern circumpacific regions, where it occurred approx. 4 cal kyr BP, as shown by many Altiplano lacustrine (Jenny et al., 2002; Paduano et al., 2003; Valero-Garcés et al., 2005) and marine records (Lamy et al., 2001).

The peat growth rate at Rano Aroi recovered completely at 2.5 cal kyr BP, and relatively humid conditions were inferred up to the present time. A more humid Late Holocene is a consistent regional pattern that has been observed at tropical to temperate latitudes (Lamy et al., 2001; Valero-Garcés et al., 2005; Conroy et al., 2008). The regional shift to wetter conditions after 4 cal kyr in eastern Pacific areas has been related to stronger convective summer rains due to increased summer insolation together with a northward shift of the Southern Westerlies.

At 1.3 cal kyr BP (655 AD), a decrease in $\mathrm{C} / \mathrm{N}$ suggests enhanced mineralization, and high $\delta^{13} \mathrm{C}$ values indicate a higher contribution of $\mathrm{C}_{4}$ grass organic matter. The age of this event lies in the time interval proposed for human arrival or expansion (Rull et al., 2010a), so these features could be interpreted as peat exposure and vegetation opening caused by anthropogenic disturbance. Nevertheless, this event could also reflect climate change during the Medieval Climate Anomaly (1205-705 yr cal BP), which brought warm and dry conditions, a low degree of interannual variability and less storminess to the eastern Pacific (Nunn, 2007).

\section{Conclusions}

The Rano Aroi sequence is the oldest and longest terrestrial record recovered on Easter Island, spanning the last $70 \mathrm{kyr} B P$ and documenting water level and vegetation changes during the Late Pleistocene. Radicel peat facies indicate that Rano Aroi grew as a kettle hole mire from a formerly dry basin, creating impervious layers on increasingly higher levels. The geochemical record and peat characterization allow us to define three peatland types depending on the hydrological conditions: (1) baseline mire conditions (Facies A and B), (2) flooded mire (Facies C) formed during periods of enhanced precipitation and (3) dry mire (Facies D) when drier conditions prevailed. 
During MIS 4 (70 to 60 kyr BP in Rano Aroi), the hydric and environmental conditions in the mire were stable and resembled mire baseline conditions. The MIS 3 (60 to $27.8 \mathrm{cal} \mathrm{kyr} \mathrm{BP}$ ) is characterized by the occurrence of abrupt wet events owing to the progressive increase of humidity. After $45 \mathrm{kyr}$ BP vegetation in Rano Aroi changed from $C_{4}$ to $C_{3}$ plant dominance, which might have been triggered by more adequate conditions for sedge colonization or by the arrival of S. californicus to the island. Late MIS 3 was a very dry period, which led to peat oxidation and exposure shortly after 39 cal kyr BP.

During early MIS 2 (27.8-19 cal kyr BP), peat accumulation rates were low, apparently due to cold conditions, which will have hampered vegetation development. Evidence of the onset of deglaciation is concordant with Raraku Lake environmental development and was dated at $17.5 \mathrm{cal}$ kyr BP at Rano Aroi, when peat accumulation rates began to increase again. The regional mid-Holocene dry period is well characterized at Rano Aroi from 5 to 2.5 cal kyr BP.

Our Rano Aroi record shows a development that is in accordance with regional paleoclimate records and illustrates the terrestrial response to the main Late Pleistocene phases in the Pacific region in terms of vegetation and paleo-hydrological change. The lack of sedimentary sequences that indicate Late Pleistocene precipitation over the remote Pacific region demands further studies into the correlation among circumpacific series to characterize the moisture distribution mechanisms from a regional perspective. Additional work is required to understand the interplay of ENSO patterns, SPCZ interglacial position and high-latitude responses over atmospheric features. Future work on the understanding of the Rano Aroi record and regional correlation will provide a unique opportunity to understand millennial-scale climate features over the southern Pacific Ocean.

\section{Acknowledgments}

This research was funded by the Spanish Ministry of Science and Education through the projects LAVOLTER (CGL2004-00683/BTE), GEOBILA (CGL2007-60932/BTE) and CONSOLIDER GRACCIE (CSD2007-00067) and an undergraduate grant JAE (BOE 04/03/2008) to Olga Margalef. We thank CONAF (Chile) and the Riroroko family for the facilities provided on Easter Island, Anders Noren and Erik Brown for their valuable guidance in the process of obtaining XRF data at the LacCore/Limnological Research Center (LRC) and Large Lake Observatory (LLO) (University of Minnesota) and Hilary Birks, Torstein Solhøy and Heinrich Schwartz for their help in macrofossil identification. We also thank John Couwenberg, Martin Theuerkauf, Annie Wojatschke, Almut Spangenberg, Dierk Michaelis and René Dommain for their help and contributions to the peat facies descriptions and peatland characterization during the stay of $\mathrm{OM}$ at the University of Greifswald.

\section{References}

Anderson, A., Chappell, J., Gagan, M., Grove, R., 2006. Prehistoric maritime migration in the Pacific Islands: an hypothesis of ENSO forcing. The Holocene 16 (1), 1-6.

Aucour, A.-M., Bonnefille, R., Hillaire-Marcel, C., 1999. Sources and accumulation rates of organic carbon in an equatorial peat bog (Burundi, East Africa) during the Holocene: carbon isotope constraints. Palaeogeography, Palaeoclimatology, Palaeoecology 150, 179-189.

Azizi, G., Flenley, J.R., 2008. The last glacial maximum climatic conditions on Easter Island. Quaternary International 184, 166-176.

Baker, P.E., Buckley, F., Holland, J.G., 1974. Petrology and geochemistry of Easter Island. Contributions to Mineralogy and Petrology 44, 85-100.

Baker, P.A., Rigsby, C.A., Seltzer, G.O., Fritz, S.C., Lowenstein, T.K., Bacher, N.P., Veliz, C., 2001. Tropical climate changes at millennial and orbital timescales on the Bolivian Altiplano. Nature 409, 698-700. http://dx.doi.org/10.1038/35055524.

Barber, K.E., Chambers, F.M., Maddy, D., 2003. Holocene palaeoclimates from peat stratigraphy: macrofossil proxy climate records from three oceanic raised bogs in England and Ireland. Quaternary Science Reviews 22, 521-539.

Bindler, R., 2006. Mired in the past-looking to the future: geochemistry of peat and the analysis of past environmental changes. Global and Planetary Change 53, 209-221.

Birks, H.H., 2001. Plant macrofossils. In: Smol, J.P., Birks, H.J.B., Last, W.M. (Eds.), Tracking Environmental Change Using Lake Sediments, vol. 3. Kluwer, Dordrecht, pp. 49-74.
Birks, H.H., Birks, H.J.B., 2006. Multiproxy studies in palaeolimnology. Vegetation History and Archaeobotany 15, 235-251.

Blunier, T., Brook, E.J., 2001. Timing of millennial-scale climate change in Antarctica and Greenland during the last glacial period. Science 291, 109-112.

Butler, K., Prior, C.A., Flenley, J.R., 2004. Anomalous radiocarbon dates from Easter Island. Radiocarbon 46, 395-405.

Cañellas-Boltá, N., Rull, V., Sáez, A., Margalef, O., Giralt, S., Pueyo, J.J., Birks, H.H., Birks, H.J.B., Pla-Rabes, S., 2012. Macrofossils in Raraku Lake (Easter Island) integrated with sedimentary and geochemical records: towards a paleoecological synthesis. Quaternary Science Reviews 34, 113-126.

Clement, A.C., Peterson, L.C., 2008. Mechanisms of abrupt climate change of the last glacial period. Reviews of Geophysics 46. http://dx.doi.org/10.1029/2006RG000204.

Conroy, J.L., Overpeck, J.T., Cole, J.E., Shanahan, T.M., Steinitz-Kannan, M., 2008. Holocene changes in eastern tropical Pacific climate inferred from a Galápagos lake sediment record. Quaternary Science Reviews 27 (11-12), 1166-1180.

Couwenberg, J., De Klerk, P., Endtmann, E., Joosten, H., Michaelis, D., 2001. Hydrogenetische Moortypen in der Zeit - eine Zusammenschau (Hydrogenetic mire types in time-an overview). In: Succow, M., Joosten, H. (Eds.), Landschaftsökologische Moorkunde. (Landscape Ecology of Peatlands), Second edition. Schweizerbart, Stuttgart, pp. 399-403 (in German).

Damman, A.W.H., Tolonen, K., Sallantaus, T., 1992. Element retention and removal in ombrotrophic peat of Hådetkeidas, a boreal Finnish peat bog. Suo 43, 137-145.

Danzeglocke, U., Jöris, O., Weninger, B., 2008. CalPal-2007 online. http://www.calpalonline.de/ (accessed 2009.05.03).

de Jong, R., Blaauw, M., Chambers, F.M., Christensen, T.R., de Vleeschouwer, F., Finsinger, W., Fronzek, S., Johansson, M., Kokfelt, U., Lamentowicz, M., Le Roux, G., Mauquoy, D., Mitchell, E.A.D., Nichols, J.E., Samaritani, E., van Geel, B., 2010. Climate and peatlands. In: Dodson, J. (Ed.), Changing Climates, Earth Systems and Society. Springer, Dordrecht, pp. 85-121.

Dickinson, W.R., 2001. Paleoshoreline record of relative Holocene sea levels on Pacific islands. Earth-Science Reviews 55, 191-234.

Dommain, R., Couwenberg, J., Joosten, H., 2011. Development and carbon sequestration of tropical peat domes in south-east Asia: links to post-glacial sea-level changes and Holocene climate variability. Quaternary Science Reviews 30 (7-8), 999-1010.

Dumont, H.J., Cocquyt, C., Fontugne, M., Arnold, M., Reyss, J.-L., Bloemendal, J., Oldfield, F., Steenbergen, C.L.M., Korthals, H.J., Zeeb, B.A., 1998. The end of moai quarrying and its effect on Raraku Lake, Easter Island. Journal of Paleolimnology 20, 409-422.

Ehleringer, J.R., Cerling, T.E., Helliker, B.R., 1997. C4 photosynthesis, atmospheric $\mathrm{CO}_{2}$ and climate. Oecologia 112, 285-299.

Etienne, M., Michea, G., Díaz, E., 1982. Flora, vegetación y potencial pastoral de la Isla de Pascua. Boletín Técnico $\mathrm{n}^{\circ}$ 47, Facultad de Ciencias Agrarias, Veterinarias y Forestales.Universidad de Chile, Santiago de Chile (in Spanish).

Flenley, J.R., King, S.M., 1984. Late Quaternary pollen records from Easter Island. Nature 307, 47-50.

Flenley, J.R., King, S.M., Jackson, J., Chew, C., Teller, J.T., Prentice, M.E., 1991. The Late Quaternary vegetational and climatic history of Easter Island. Journal of Quaternary Science 6, 85-115.

Gaudig, G., Couwenberg, J., Joosten, H., 2006. Peat accumulation in kettle holes: bottom up or top down? Mires and Peat 1 (6), 1-16 (http://www.mires-and-peat.net/ map01/map_1_6.htm).

Genz, J., Hunt, T.L., 2003. El Niño Southern Oscillation and Rapa Nui prehistory. Rapa Nui Journal 17 (1), 7-14.

González-Ferran, O., Mazzuoli, R., Lahsen, A., 2004. In: Centro de Estudios Volcanológicos (Ed.), Geoloía del Complejo Volcánico Isla de Pascua Rapa Nui Santiago-Chile.1:30.000 Geol. map, (in Spanish).

Gorham, E., 1991. Northern peatlands: role in the carbon cycle and probable response to climatic warming. Ecological Applications 1, 182-195.

Gorham, E., Janssens, J.J., 2005. The distribution and accumulation of chemical elements in five peat cores from the mid-continent to the eastern coast of North America. Wetlands 25, 259-278.

Gossen, C., 2007. Report: the mystery lies in the Scirpus. Rapa Nui Journal 21 (2), 105-110.

Grootjans, A.P., Adema, E.B., Bleuten, W., Joosten, H., Madaras, M., Janáková, M., 2006. Hydrological landscape settings of base-rich fen mires and fen meadows: an overview. Applied Vegetation Science 9, 175-184.

Hanebuth, T., Stattegger, K., Grootes, P.M., 2000. Rapid flooding of the Sunda Shelf: a late-glacial sea-level record. Science 288, 1033-1035.

Haug, G.H., Hughen, K.A., Sigman, D.M., Peterson, L.C., Röhl, U., 2001. Southward migration of the Intertropical Convergence Zone through the Holocene. Science 293, 1304-1308. http://dx.doi.org/10.1126/science.1059725.

Heirman, K., 2011. A Wind of Change': Changes in Position and Intensity of the Southern Hemisphere Westerlies During Oxygen Isotope Stages 3, 2 and 1. PhD Thesis Ghent University.

Heiser, C.B., 1974. Totoras, Taxonomy, and Thor, vol. 20 no. 2. Botanical Society of America, Inc.

Herrera, C., Custodio, E., 2008. Conceptual hydrogeological model of volcanic Easter Island (Chile) after chemical and isotopic surveys. Hydrogeology Journal. http://dx.doi.org/10.1007/s10040-008-0316-z.

Heusser, C.J., Heusser, L.E., 2006. Submillennial palynology and palaeoecology of the last glaciation at Taiquemo (50 $000 \mathrm{cal} \mathrm{yr}$, MIS 2-4) in southern Chile. Quaternary Science Reviews 25, 446-454.

Hong, Y.T., Wang, Z.G., Jiang, H.B., Lin, Q.H., Hong, B., Zhu, Y.X., Wang, Y., Xu, L.S., Leng, X.T., Li, H.D., 2001. A 6000-year record of changes in drought and precipitation in northeastern China based on a ${ }^{13} \mathrm{C}$ time series from peat cellulose. Earth and Planetary Science Letters 185, 111-119. 
Horrocks, M., Wozniak, J.A., 2008. Plant microfossil analysis reveals disturbed fores and mixed-crop, dryland production system at Te Niu, Easter Island. Journal of $\mathrm{Ar}$ chaeological Science 35, 126-142.

Huang, Y., Street-Perrott, F.A., Perrott, R.A., Metzger, P., Eglinton, G., 1999. Glacial-interglacial environmental changes inferred from molecular and compoundspecific $\delta^{13} \mathrm{C}$ analyses of sediment from Sacred Lake, Mt. Kenya. Geochimica et Cosmochimica Acta 63, 1383-1404.

Ingolfsson, O., Hjort, C., Berkman, P.A., Bjfrck, S., Colhoun, E., Goodwin, I.D., Hall, B., Hirakawa, K., Melles, M., Mfller, P., Prentice, L., 1998. Antarctic glacial history since the last glacial maximum: an overview of the record on land. Antarctic Science 10, 326-344.

Jackson, S.T., Charman, D. (Eds.), 2010. Special issue on "Peatlands: Paleoenvironments and Carbon Dynamics": PAGES News, vol. 18 (Number).

Jenny, B., Valero-Garcés, B.L., Villa-Martinez, R., Urrutia, R., Geyh, M., Veit, H., 2002 Early to mid-Holocene aridity in central Chile and the southern westerlies: the Laguna Aculeo record $\left(34^{\circ} \mathrm{S}\right)$. Quaternary Research 58, 160-170.

Joosten, H., Clarke, D., 2002. Wise Use of Mires and Peatlands-Background Principles Including a Framework for Decision-Making. International Mire Conservation Group and International Peat Society, Saarijärvi, Finland.

Junk, C., Claussen, M., 2011. Simulated climate variability in the region of Rapa Nui during the last millennium. Climate of the Past 7, 579-586. http://dx.doi.org/10.5194/cp-7 579-2011.

Kaiser, J., Lamy, F., Hebbeln, D., 2005. A 70-kyr sea surface temperature record off southern Chile (ODP Site 1233). Paleoceanography 20, PA4009. http://dx.doi.org/ 10.1029/2005PA001146.

Kaiser, J., Schefub, E., Lamy, F., Mohtadi, M., Hebbeln, D., 2008. Glacial to Holocene changes in sea surface temperature and coastal vegetation in north central Chile: high versus low latitude forcing. Quaternary Science Reviews 27, 2064-2075.

Koutavas, A., Lynch-Stieglitz, J., Marchitto Jr., T.M., Sachs, J.P., 2002. El Niño-like pattern in Ice Age Tropical Pacific sea surface temperature. Science 297, 226-230.

Kylander, M.E., Muller, J., Weiss, D.J., Wuest, R.A.F., Gallagher, K., Garcia-Sanchez, R., Coles, B.J., 2007. Rare Earth Element and $\mathrm{Pb}$ isotope variations in a 55,000 year old peat core from Lynch's Crater (NE Queensland, Australia): applications to paleoclimate in the Southern Hemisphere. Geochimica et Cosmochimica Acta 71 (4), 942-960.

Lambeck, K., Chappell, J., 2001. Sea level change through the last glacial cycle. Science 292, 679-686.

Lamy, F., Hebbeln, D., Wefer, G., 1998. Late Quaternary precessional cycles of terrigenous sediment input off the Norte Chico, Chile (27.5S) and palaeoclimatic implications. Palaeogeography, Palaeoclimatology, Palaeoecology 141, 233-251.

Lamy, F., Hebbeln, D., Röhl, U., Wefer, G., 2001. Holocene rainfall variability in southern Chile: a marine record of latitudinal shifts of the Southern Westerlies. Earth and Planetary Science Letters 185, 369-382.

Lea, D.W., Pak, D.K., Belanger, C.L., Spero, H.J., Hall, M.A., Shackleton, N.J., 2006 Paleoclimate history of Galápagos surface waters over the last 135,000 yr. Quaternary Science Reviews 25, 1152-1167.

Leduc, G., Vidal, L., Tachikawa, K., Rostek, F., Sonzogni, C., Beaufort, L., Bard, E., 2007 Moisture transport across Central America as a positive feedback on abrupt climatic changes. Nature 445, 908-911.

MacIntyre, F., 2001a. ENSO, climate variability, and the Rapanui: part I. The basics. Rapa Nui Journal 15 (1), 17-26.

MacIntyre, F., 2001b. ENSO, climate variability, and the Rapanui: part II. Oceanography and Rapa Nui. Rapa Nui Journal 15 (2), 83-94.

Mann, D., Edwards, J., Chase, J., Beck, W., Reanier, R., Mass, M., Finney, B., Loret, J., 2008 Drought, vegetation change, and human history on Rapa Nui (Isla de Pascua, Easter Island). Quaternary Research 69, 201-206.

Mayewski, P.A., Rohling, E.E., Stager, J.C., Karlen, W., Maasch, K.A., Meeker, L.D. Meyerson, E.A., Gasse, F., van Kreveld, S., Holmgren, K., Lee-Thorp, J., Rosqvist, G. Rack, F., Staubwasser, M., Schneider, R.R., Steig, E.J., 2004. Holocene climate variability. Quaternary Research 62, 243-255.

Meyers, P.A., 1994. Preservation of elemental and isotopic source identification of sedimentary organic matter. Chemical Geology 114, 289-302.

Meyers, P.A., Terranes, J.L., 2001. Sediment organic matter. In: Last, W.M., Smol, J.P. (Eds.), Tracking Environmental Change Using Lake Sediments. : Physical and Geochemical Techniques, 2. Kluwer Academic Publishers, Dordrecht, The Netherlands, pp. 239-269.

Moreno, P.I., León, A.L., 2003. Abrupt vegetation changes during the last glacial to Holocene transition in mid-latitude South America. Journal of Quaternary Science 18, 787-800.

Mucciarone, D.A., Dunbar, R.B., 2003. Stable isotope record of El Niño-Southern Oscillation events from eastern island. In: Loret, J., Tanacredi, J.T. (Eds.), Easter Island: Scientific Exploration into the World's Environmental Problems in Microcosm. Kluwer Academic/Plenum, New York, pp. 113-132.

Muller, J., 2006. Reconstructing climate change of the last 55 kyr: the Lynch's Crater peat mire record, NE-QLD, Australia. PhD thesis James Cook University.

Muller, J., Wüst, R.A.J., Weiss, D.J., Hu, Y., 2006. Geochemical and stratigraphic evidence of environmental change at Lynch's Crater, Queensland, Australia. Global and Planetary Change 53, 269-277.

Muller, J., Kylander, M.E., Martinez Cortizas, A., Wüst, R.A., Weiss, D.J., Blake, K., Coles, B.J., Garcia-Sanchez, R., 2008. The use of principle component analyses in characterising trace and major elemental distribution in a $55 \mathrm{kyr}$ peat deposit in tropical Australia: implications to paleoclimate. Geochimica et Cosmochimica Acta 72, 449-463.

Nunn, P.D., 2007. Climate, Environment and Society in the Pacific During the Last Millennium. Elsevier, Amsterdam.

Oksanen, J., Kindt, R., Legendre, P., O'Hara, R.B., 2006. vegan: Community Ecology Package. R package version 1.8-3. URL http://CRAN.R-project.org/.

Oppo, D.W., Linsley, B.K., Rosental, Y., Dannenmann, S., Beaufort, L., 2003. Orbital and suborbital climate variability in the Sulu Sea, western tropical Pacific. Geochemistry, Geophysics, Geosystems 4 (20 pp.).
Orliac, C., 2000. The woody vegetation of Easter Island between the early 14th and the mid-17th centuries A.D. In: Stevenson, C., Ayres, W. (Eds.), Easter Island Archaeology: Research on Early Rapanui Culture. Easter Island Foundation, Los Osos.

Orliac, C., Orliac, M., 1998. The disappearance of Easter Island's forest: overexploitation or climatic catastrophe? In: Stevenson, C., Lee, G., Morin, F.J. (Eds.), Easter Island in Pacific Context: South Seas Symposium. : Proceedings of the Fourth International Conference on Easter Island and East Polynesia. Easter Island Foundation, Los Osos, pp. 129-134.

Paduano, G.M., Bush, M.B., Baker, P.A., Fritz, S.C., Seltzer, G.O., 2003. A vegetation and fire history of Lake Titicaca since the Last Glacial Maximum. Palaeogeography, Palaeoclimatology, Palaeoecology 194, 259-279.

Page, S.E., Rieley, J.O., Wüst, R.A.J., 2006. Lowland tropical peatlands of Southeast Asia. In: Martini, I.P., Martinez Cortizas, A., Chesworth, W. (Eds.), Peatlands: Evolution and Records of Environmental and Climate Changes: Developments in Earth Surface Processes, vol. 9 .

Pena, L.D., Cacho, I., Ferretti, P., Hall, M.A., 2008. El Niño-Southern Oscillation-like variability during glacial terminations and interlatitudinal teleconnections. Paleoceanography 23 , PA3101. http://dx.doi.org/10.1029/2008PA001620.

Peteet, D., Beck, W., Ortiz, J., O'Connell, S., Kurdyla, D., Mann, D., 2003. Rapid vegetational and sediment change from Rano Aroi crater, Easter Island. In: Loret, J. Tanacredi, J.T. (Eds.), Scientific Exploration into the World's Environmental Problems in Microcosm. Kluwer Academic/Plenum Publ., New York, pp. 81-92.

R Development Core Team, 2011. R: a language and environment for statistical computing. R Foundation for Statistical Computing, Vienna, Austria. (http://www.Rproject.org/).

Reimer, P.J., Baillie, M.G.L., Bard, E., Bayliss, A., Beck, J.W., Bertrand, C.J.H., Blackwell, P.G. Buck, C.E., Burr, G.S., Cutler, K.B., Damon, P.E., Edwards, R.L., Fairbanks, R.G. Friedrich, M., Guilderson, T.P., Hogg, A.G., Hughen, K.A., Kromer, B., McCormac, G., Manning, S., Ramsey, C.B., Reimer, R.W., Remmele, S., Southon, J.R., Stuiver, M., Talamo, S., Taylor, F.W., van der Plicht, J., Weyhenmeyer, C.E., 2004. IntCal04 terrestrial radiocarbon age calibration, 0-26 cal kyr BP. Radiocarbon 46, 1029-1058.

Rull, V., Cañellas-Boltà, N., Sáez, A., Giralt, S., Pla, S., Margalef, O., 2010a. Paleoecology of Easter Island: evidence and uncertainties. Earth-Science Reviews 99, 50-60.

Rull, V., Stansell, N.D., Montoya, E., Bezada, M., Abbott, M.B., 2010b. Palynological signal of the Younger Dryas in tropical Venezuelan Andes. Quaternary Science Reviews 29, 3045-3056.

Sáez, A., Valero-Garcés, B., Giralt, S., Moreno, A., Bao, R., Pueyo, J.J., Hernández, A., Casas, D., 2009. Glacial to Holocene climate changes in the SE Pacific. the Raraku Lake sedimentary record (Easter Island, $27^{\circ} \mathrm{S}$ ). Ouaternary Science Reviews 28, 2743-2759.

Shotyk, W., 1996. Peat bogs archives of atmospheric metal deposition: geochemical assessment of peat profiles, natural variations in metal concentrations, and metal enrichment factors. Environmental Reviews 4, 149-183.

Shotyk, W., Weiss, D., Kramers, J.D., Frei, R., Cheburkin, A.K., Gloor, M., Reese, S., 2001 Geochemistry of the peat bog at Etang de la Gruère, Jura Mountains, Switzerland, and its record of atmospheric $\mathrm{Pb}$ and lithogenic trace metals ( $\mathrm{Sc}, \mathrm{Ti}, \mathrm{Y}, \mathrm{Zr}$, and REE) since $12,370{ }^{14} \mathrm{C}$ yr BP. Geochimica et Cosmochimica Acta 65, 2337-2360.

Street-Perrott, F.A., Huang, Y., Perrott, R.A., Eglington, G., Barker, P., Ben Khelifa, L. Harkness, D.D., Olago, D.O., 1997. Impact of lower atmospheric $\mathrm{CO}_{2}$ on tropical mountain ecosystems. Science 278, 1422-1426.

Street-Perrott, F.A., Ficken, K., Huang, Y., Eglinton, G., 2004. Late quaternary changes in carbon cycling on Mt. Kenya, East Africa: an overview of the record in lacustrine organic matter. Quaternary Science Reviews 23, 861-879.

Stuut, J.W., Lamy, F., 2004. Climate variability at the southern boundaries of the Namib (southwestern Africa) and Atacama (northern Chile) coastal deserts during the last 120,000 yr. Quaternary Research 62.

Succow, M., Joosten, H., 2001. Landschaftsökologische Moorkunde. Sweizerbart, Stuttgart (622 pp.).

Talbot, M.R., Johannessen, T., 1992. A high resolution palaeoclimatic record for the last 27,500 years in tropical West Africa from the carbon and nitrogen isotopic composition of lacustrine organic matter. Earth and Planetary Science Letters 110, 23-37.

Tapia, P.M., Fritz, S.C., Baker, P.A., Seltzer, G.O., Dunbar, R.B., 2003. A Late Quaternary diatom record of tropical climatic history from Lake Titicaca (Peru and Bolivia). Palaeogeography, Palaeoclimatology, Palaeoecology 194, 139-164.

Valero-Garcés, B.L., Jenny, B., Rondanelli, M., Delgado-Huertas, A., Burns, S.J., Veit, H., Moreno, A., 2005. Palaeohydrology of Laguna de Tagua Tagua $\left(34^{\circ} 30^{\prime} \mathrm{S}\right)$ and moisture fluctuations in Central Chile for the last 46,000 yr. Journal of Quaternary Science 20, 625-641.

van Geel, B., Heusser, C.J., Renssen, H., Shuurmans, C.J.E., 2000. Climatic change in Chile at around $2700 \mathrm{BP}$ and global evidence for solar forcing: a hypothesis. The Holocene 10, 659-664.

Wang, X., Auler, A.S., Edwards, R.L., Cheng, H., Cristalli, P.S., Smart, P.L., Richards, D.A Shen, C.-C., 2004. Wet periods in northeastern Brazil over the past $210 \mathrm{kyr}$ linked to distant climate anomalies. Nature 432, 740-743. http://dx.doi.org/10.1038/ nature03067.

Wang, X., Auler, A.S., Edwards, R.L., Cheng, H., Ito, E., Wang, Y., Kong, X., Solheid, M., 2007. Millennial-scale precipitation changes in southern Brazil over the past 90,000 years. Geophysical Research Letters 34, L23701. http://dx.doi.org/10.1029/2007GL031149.

Weber, C.A., 1930. Grenzhorizont und älterer Sphagnumtorf. Abhandlungen Naturwissenschaftlicher Verein Bremen 28, 57-65.

Weiss, D., Shotyk, W., Rieley, J.O., Page, S.E., Gloor, M., Reese, S., Cortizas-Martínez, A. 2002. The geochemistry of major and selected trace elements in a forested peat bog, Kalimantan, SE Asia, and its implications for past atmospheric dust deposition. Geochimica et Cosmochimica Acta 66, 2307-2323.

Weninger, B., Jöris, O., Danzeglocke, U., 2008. CalPal-2007. Cologne Radiocarbon Calibration \& Palaeoclimate Research Package.

Zizka, G., 1991. Flowering plants of Easter Island. Palmarum Hortus Francofurtensis Scientific Reports, 3, pp. 1-108. 